Portland State University

PDXScholar

3-14-1986

\title{
The Effect of Salinity on Habitat Selection of Two Oregon Chiton Species (Katharina Tunicata and Mopalia Hindsii)
}

David Carl Rostal

Portland State University

Follow this and additional works at: https://pdxscholar.library.pdx.edu/open_access_etds

Part of the Biology Commons, and the Physiology Commons Let us know how access to this document benefits you.

Recommended Citation

Rostal, David Carl, "The Effect of Salinity on Habitat Selection of Two Oregon Chiton Species (Katharina Tunicata and Mopalia Hindsii)" (1986). Dissertations and Theses. Paper 3688.

https://doi.org/10.15760/etd.5572

This Thesis is brought to you for free and open access. It has been accepted for inclusion in Dissertations and Theses by an authorized administrator of PDXScholar. Please contact us if we can make this document more accessible: pdxscholar@pdx.edu. 
AN ABSTRACT OF THE THESIS OF David Carl Rostal for the Master of Science in Biology presented March 14, 1986.

Title: The Effect of Salinity on Habitat Selection of Two Oregon Chiton Species (Katharina tunicata and Mopalia hindsii).

APPROVED BY MEMBERS OF THE THESIS COMMITTEE:

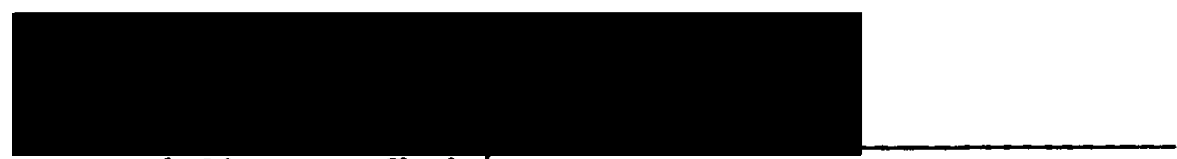
Leonard Simpson, Chairman

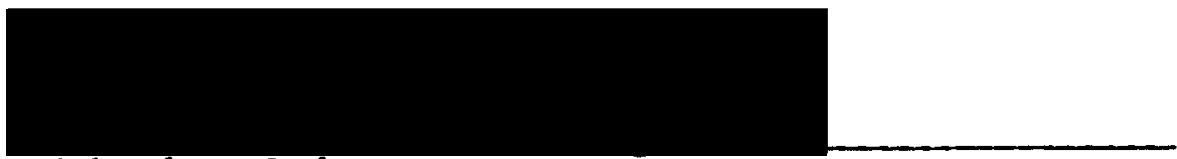
Richard B. Forbes

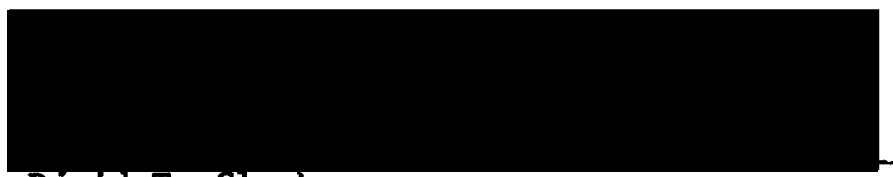

Dávid T. Clark

Adult specimens of Katharina tunicata (mean weight $=10.23$ grams) and Mopalia hindsil (mean weight $=10.90$ grams) were tested for osmotic stress tolerance and oxygen consumption rates in a series of salinities $\left(120 \%, 100 \%, 80 \%, 60 \%\right.$, and $40 \%$ seawater) at $11^{\circ} \mathrm{C}$ and $16 \mathrm{~L}: 8 \mathrm{D}$ photoperiod.

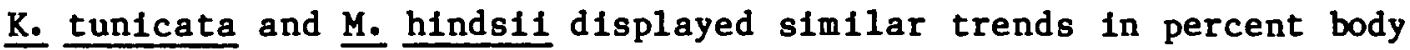
weight variation and volume regulatory responses to osmotic stress. However, $\mathrm{K}_{-}$tunicata experienced a significantly higher percent body weight increase than did $\underline{M}$. hindsil in response to hypo-osmotic conditions ( $80 \%, 60 \%$, and $40 \%$ seawater). The mean rates of oxygen 
consumption per salinity for the two species were not significantly different. Both species, however, showed reduced oxygen consumption rates and significantly increased weight gain in $40 \%$ seawater. SEM comparisons of radulae, ctenidia, and shape of the pallial groove revealed no significant differences between the species relevant to differences observed in habitat selection.

Salinity was measured bimonthly at the two study sites ( $\underline{K}$.

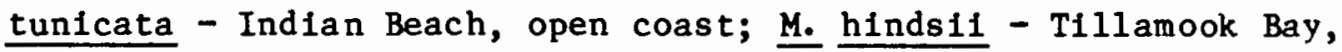
brackish) during low tide from January 1985 to June 1985. Salinity measurements revealed a difference in mean salinity between study sites of $12 \%$ seawater.

Dominant macroalgal species were identified for the two study sites. Variation in dominant macroalgal species between study sites reflected published dietary preferences; $K_{0}$ tunicata feeds on Hedophyllum sessile, while M. hindsii feeds on Gigartina spp. and animal material. K. tunicata is generally restricted to open coast habitats and is considered stenohaline in nature, while M. hindsii is common to open coast as we11 as slightly brackish habitats and is considered euryhaline in nature.

The results of this study suggest that both species are osmoconformers with equivalent volume regulatory capabilities and are both euryhaline in nature. Other factors such as diet, larval settling responses, and interspecific competition may be involved in the difference observed in the habitat selection of $K_{0}$ tunicata and $\underline{M}_{-} \underline{\text { hindsil. }}$ Salinity appears not to be a major influence on habitat selection by these chiton species. 
THE EFFECT OF SALINITY ON HABITAT

SELECTION OF TWO OREGON CHITON SPECIES

(Katharina tunicata AND Mopalia hindsi1)

by

DAVID CARL ROSTAL

A thesis submitted in partial fulfillment of the requirements for the degree of

MASTER OF SCIENCE

in

BIOLOGY

Portland State University

1986 
TO THE OFFICE OF GRADUATE STUDIES AND RESEARCH:

The members of the Committee approve the thesis of David Car 1 Rostal presented March 14, 1986.

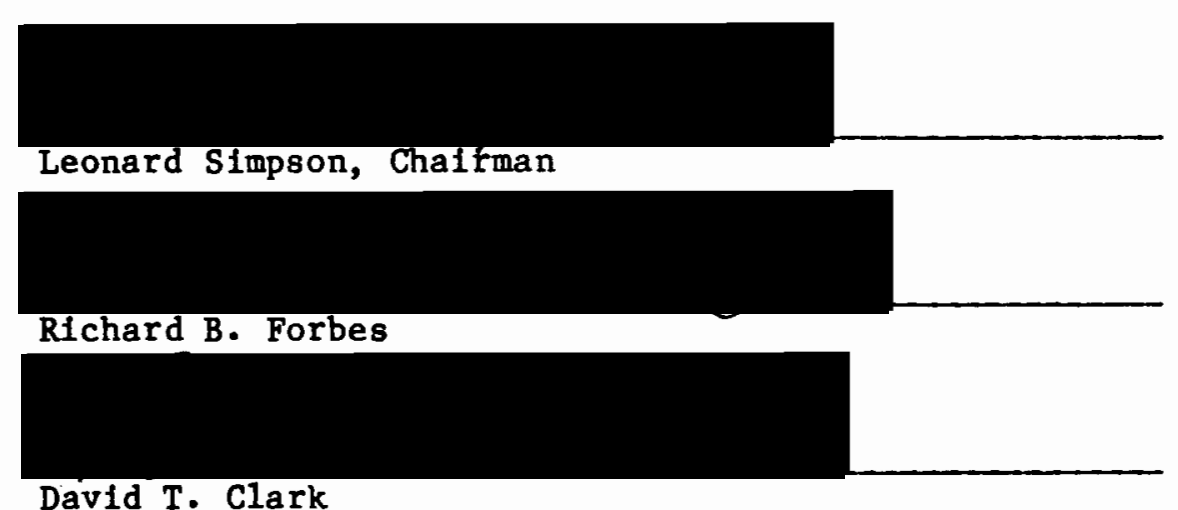

David T. Clark

APPROVED :

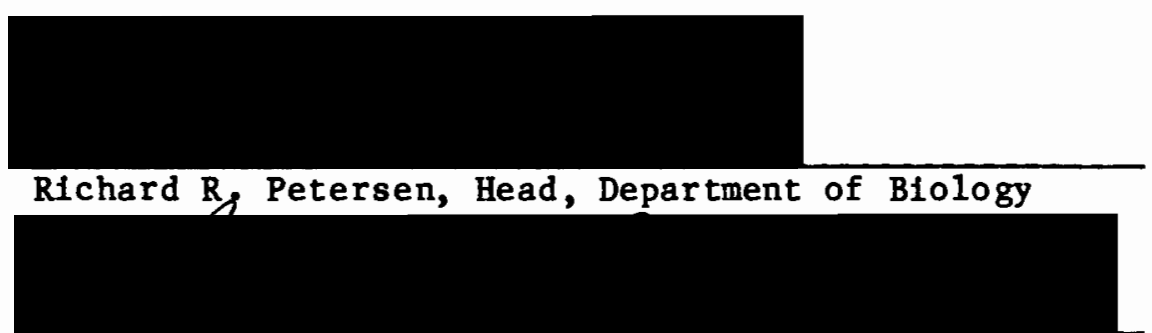

Bernard Ross, Dean of Graduate Studies and Research 


\section{ACKNOWLEDGMENTS}

I would like to thank my advisor, Dr. Leonard Simpson, and members of my committee, Drs. Richard B. Forbes and David T. Clark, for their support and valuable criticlsm of my manuscript. My thanks are extended to Michael C. Webb and Dr. W. H. Fahrenbach of the Oregon Regional Primate Research Center (ORPRC) for their Invaluable assistance and techniques with the scanning electron microscope. I would also like to thank Joel Ito, Katie Simon, and Harry J. Wohlsein of the ORPRC for their assistance with the graphic and photographic components of my thesis. My thanks to Gerald M. Bell of the Department of Environmental Quality for his technical assistance and avallability of the salinity meter. I would like to thank Alfred B. Lord, graduate student, for his assistance and support with data collection in the field. Finally, I would like to acknowledge my mother, Nita D. Rostal, for her encouragement and support of my graduate studies and research. 
TABLE OF CONTENTS

PAGE

ACKNOWLEDGMENTS $\ldots \ldots \ldots \ldots \ldots \ldots \ldots \ldots \ldots \ldots \ldots \ldots \ldots \ldots \ldots \ldots \ldots$ ii

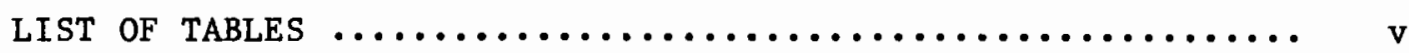

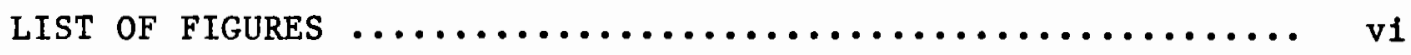

CHAPTER

I INTRODUCTION $\ldots \ldots \ldots \ldots \ldots \ldots \ldots \ldots \ldots \ldots \ldots \ldots \ldots \ldots \ldots \ldots, 1$

II METHODS AND TECHNIQUES

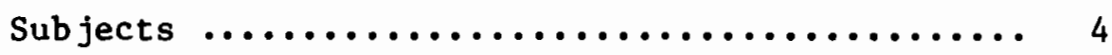

Study Sites $\ldots \ldots \ldots \ldots \ldots \ldots \ldots \ldots \ldots \ldots \ldots \ldots, 6$

Osmotic Stress Tests $\ldots \ldots \ldots \ldots \ldots \ldots \ldots \ldots \ldots, 9$

Oxygen Consumption Tests $\ldots \ldots \ldots \ldots \ldots \ldots \ldots, 9$

Morphological Comparisons $\ldots \ldots \ldots \ldots \ldots \ldots \ldots \ldots 11$

Habitat Characteristics $\ldots \ldots \ldots \ldots \ldots \ldots \ldots \ldots, 11$

Statistical Analysis $\ldots \ldots \ldots \ldots \ldots \ldots \ldots \ldots \ldots, 12$

III RESULTS

Osmotic Stress Tests .................. 13

Oxygen Consumption Tests $\ldots \ldots \ldots \ldots \ldots \ldots \ldots, 16$

Morphological Comparisons $\ldots \ldots \ldots \ldots \ldots \ldots \ldots . . \ldots$

Habitat Characteristics $\ldots \ldots \ldots \ldots \ldots \ldots \ldots \ldots, 27$

IV DISCUSSION $\ldots \ldots \ldots \ldots \ldots \ldots \ldots \ldots \ldots \ldots \ldots \ldots \ldots, 31$

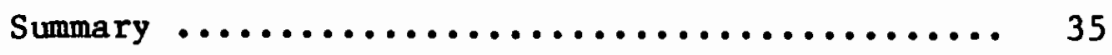

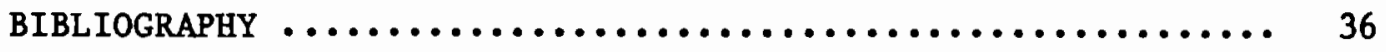




\section{LIST OF TABLES}

TABLE

PAGE

I Maximum Percent Weight Change for Two Oregon Chiton

Species (Katharina tunicata and Mopalia hindsii) in

Various Salinities ............................. 14

II Oxygen Consumption Rates $(\mu 1 / \mathrm{g} / \mathrm{hr}$ ) for Two Oregon

Chiton Species (Katharina tunicata and Mopalia hindsii)

in Various Salinities ........................ 16

II Dominant Macroalgal Species of Indian Beach, Ecola

State Park Study Site and Garibaldi, Tillamook Bay

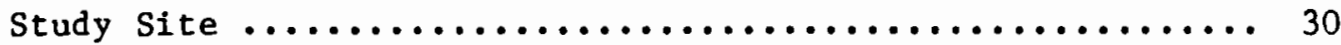




\section{LIST OF FIGURES}

FIGURE

PAGE

1. Adult specimens of Katharina tunicata (A) and

Mopalia hindsil (B) $\ldots \ldots \ldots \ldots \ldots \ldots \ldots \ldots \ldots \ldots$

2. Indian Beach, Ecola State Park study site (A) and

Garibaldi, Tillamook Bay study site (B) during

low tide $\ldots \ldots \ldots \ldots \ldots \ldots \ldots \ldots \ldots \ldots \ldots \ldots \ldots \ldots \ldots \ldots$

3. Mean monthly salinity (A, $P p t$ ) and mean monthly water

temperature $\left(B,{ }^{\circ} \mathrm{C}\right)$ for Indian Beach and Garibaldi

study sites $\ldots \ldots \ldots \ldots \ldots \ldots \ldots \ldots \ldots \ldots \ldots \ldots \ldots \ldots \ldots \ldots \ldots$

4. Osmotic stress test apparatus used to measure osmotic

stress tolerance and volume regulatory rates of

adult specimens of Katharina tunicata and

Mopalia hindsil

5. Mean percent body weight change (\% BW $\triangle$ ) and volume regulatory rates of adult specimens of Katharina tunicata and Mopalia hindsil in various test salinities over a 36 hour test period at $11^{\circ} \mathrm{C}$ and $16 \mathrm{~L}: 8 \mathrm{D}$ photoperiod 
6. Mean oxygen consumption rates $\left(\mathrm{VQ}_{2}\right)$ of adult specimens of Katharina tunicata and Mopalia hindsii in various test salinities at $11^{\circ} \mathrm{C}$ and $16 \mathrm{~L}: 8 \mathrm{D}$ photoperiod $\ldots \ldots \ldots \ldots \ldots \ldots \ldots \ldots \ldots \ldots \ldots \ldots \ldots \ldots$

7. Radulae of Katharina tunicata (A) and Mopalia

hindsii (B) revealing general organization plus grazing teeth and median teeth $\ldots \ldots \ldots \ldots \ldots \ldots$

8. Grazing teeth from radulae of Katharina tunicata (A) and Mopalla hindsii

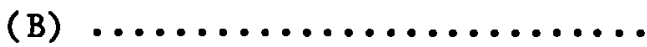

9. Median teeth from radulae of Katharina tunicata (A) and Mopalia hindsii (B) revealing the variation in the anterior tip $\ldots \ldots \ldots \ldots \ldots \ldots \ldots \ldots \ldots \ldots$

10. Ctenidia from Katharina tunicata (A) and Mopalia

hindsii (B) revealing variation in shape $\ldots . . . \ldots$

11. Surfaces of ctenidia from Katharina tunicata (A)

and Mopalia hindsil (B) revealing ciliation

and respiratory surface $\ldots \ldots \ldots \ldots \ldots \ldots \ldots \ldots \ldots \ldots$

12. Lamellar structure of ctenidia from Katharina tunicata (A)

and Mopalia hindsif (B) revealing the hemocoel, respiratory epithelium, and interlamellar

water channe1 $\ldots \ldots \ldots \ldots \ldots \ldots \ldots \ldots \ldots \ldots \ldots \ldots \ldots$

13. Pallial groove and ctenidia (ventral view) of Katharina tunicata (A) and Mopalia hindsit (B) revealing varlation in shape of groove and orlentation of ctentdia $\ldots \ldots \ldots \ldots \ldots \ldots \ldots \ldots \ldots \ldots \ldots \ldots \ldots \ldots \ldots \ldots \ldots$ 
14. Pallial groove ( $X$ - section) and ctenidia of Katharina tunicata (A) and Mopalia hindsi1 (B) revealing variation in shape of pallial groove, mantle valve, and orlentation of ctenidia $\ldots \ldots \ldots \ldots \ldots \ldots \ldots$

15. Bimonthly salinity measurements during low tide from January 1985 to June 1985 for Indlan Beach and Garibaldi study sites 
CHAPTER I

\section{INTRODUCTION}

The effect of salinity on the physiology and ecology of marine molluscs has received limited attention. Prosser (1973) stated that marine molluscs are osmoconformers with varying degrees of stenohalinity. However, more recent evidence suggests that many marine molluscs (Littorina neritoides, Collisella digitalis, Acmaea scutum, Modiolus spp., and Mopalia muscosa) possess mechanisms for active volume regulation and are euryhaline in nature (Burton, 1983).

Among the marine molluscs, the Class Polyplacophora is comprised of only one group of animals, the chitons. Chitons are characterized as a morphologically uniform group and are strictly marine. However, chitons display distinct variations in distribution, microhabitat, diet preferences, and behavior. Chitons occur along rocky shores predominantly in the intertidal zones in all seas and latitudes (Hyman, 1967). Andrus and Legard (1976) compared the habitats of 12 chiton species along the California coast and concluded that surf strength, 1ight exposure, substrate composition, moisture, and biological associates were all important in determining habitat selection.

The diet and feeding habits of many chiton species have been documented. Certain species are reported to display specific preference; e.g., Katharina tunicata feeds on Hedophyllum sessile and diatoms (Dayton, 1975; Himmelman, 1978), Tonicella lineata feeds on 
crustose coralline algae (Steneck and Watling, 1982), and Placiphore1la velata is predatory on amphipods (McLean, 1962). Other species are reported as indiscriminate or nonselective grazers, e.g., Mopalla spp. feed on Gigartina spp., Endocladia spp., Gelidium sp., (Dayton, 1975; Steneck and Watling, 1982) as well as animal material (Morris et al., 1980), Cyanoplax hartwegil feeds on Pelvetia sp., Hildenbrandia sp., Petrocelis sp., Endocladia sp., and Cladophora (Robb, 1976; Steneck and Watling, 1982), and Nuttallina californica feeds on bluegreen algae and diatoms (Nishi, 1976).

The activity patterns and behavior of chitons has been related to their ecology. Chelazzl et al. (1983) reported that variation in movement patterns of two sympatric species (Acanthopleura brevispinosa and A. gemmata) minimizes zonal overlap and reduces interspecific competition. Gómez (1976) observed a commensal association between two sympatric species (Nuttallina californica and Cyanoplax hartwegii) along the California coast.

The physiology of several chiton species has been investigated. Boyle (1969) studied the survival of Sypharochiton pelliserpentis exposed to osmotic stress conditions and concluded this species could osmoconform to salinities ranging from $50 \%$ to $150 \%$ seawater. McGill (1976) reported that Cyanoplax hartwegil is an osmoconformer over a salinity range of $75 \%$ to $125 \%$ seawater and capable of volume regulation. Simonsen (1976) found that environmental acclimation to varying salinities affected osmotic stress tolerances in Nuttallina californica. Stickle and Denoux (1976) reported that hemolymph osmotic concentration of Katharina tunicata fluctuated with tidal fluctuation in osmotic 
concentration but did not vary during exposure to air. Stickle and Ahokas (1975) postulated that Mopalia muscosa is less susceptible to osmotic stress than K. tunicata. Lebsack (1976) determined that temperature and variation in salinity from normal seawater affect oxygen consumption rates in Mopalia lignosa.

In this study, the effects of salinity on habitat selection was investigated in two Oregon chiton species, Katharina tunicata and Mopalia hindsil. $\underline{\text { K. tunicata }}$ is generally restricted to open coast habitats and is considered stenohaline in nature, while M. hindsil is common to open coast as well as slightly brackish habitats and is considered euryhaline in nature. The objectives of this study were to compare these two species with regard to their osmotic stress tolerance; their volume regulatory capabilities; the influence of salinity on oxygen consumption rates; variations in the morphology of their radulae, ctenidia, and shape of the pallial groove; and to relate physiological and morphological adaptations of $\underline{K}_{0} \underline{\text { tunicata }}$ and $\underline{M_{0}} \underline{\text { hindsii to dif- }}$ ference in their ecology and habitat selection. 
CHAPTER II

METHODS AND TECHNIQUES

$\underline{\text { Subjects }}$

Katharina tunicata range in body length to $12 \mathrm{~cm}$, are elongate to oval in shape, and have valves deeply embedded in the girdle. $\underline{K}$. tunicata possess a thick, leathery girdle which is shiny and black. They are common in the middle and low intertidal zones clinging to the sides and upper surfaces of rocks along the unprotected outer coast where they are exposed to strong wave action and direct sunlight (Fig. 1A; Morris et al., 1980).

Mopalia hindsil range in body length to $10 \mathrm{~cm}$, are oval and depressed in shape, and have well exposed valves. M. hindsil possess a "mossy" girdle which is dull and brown. They are common under rocks, on inward-sloping rock faces, or in crevices in the middle and low intertidal zones on the outer coast where surf is strong, as well as on wharf pllings in bays and even in slightly brackish waters (Fig. 1B; Morris et a 1., 1980). 


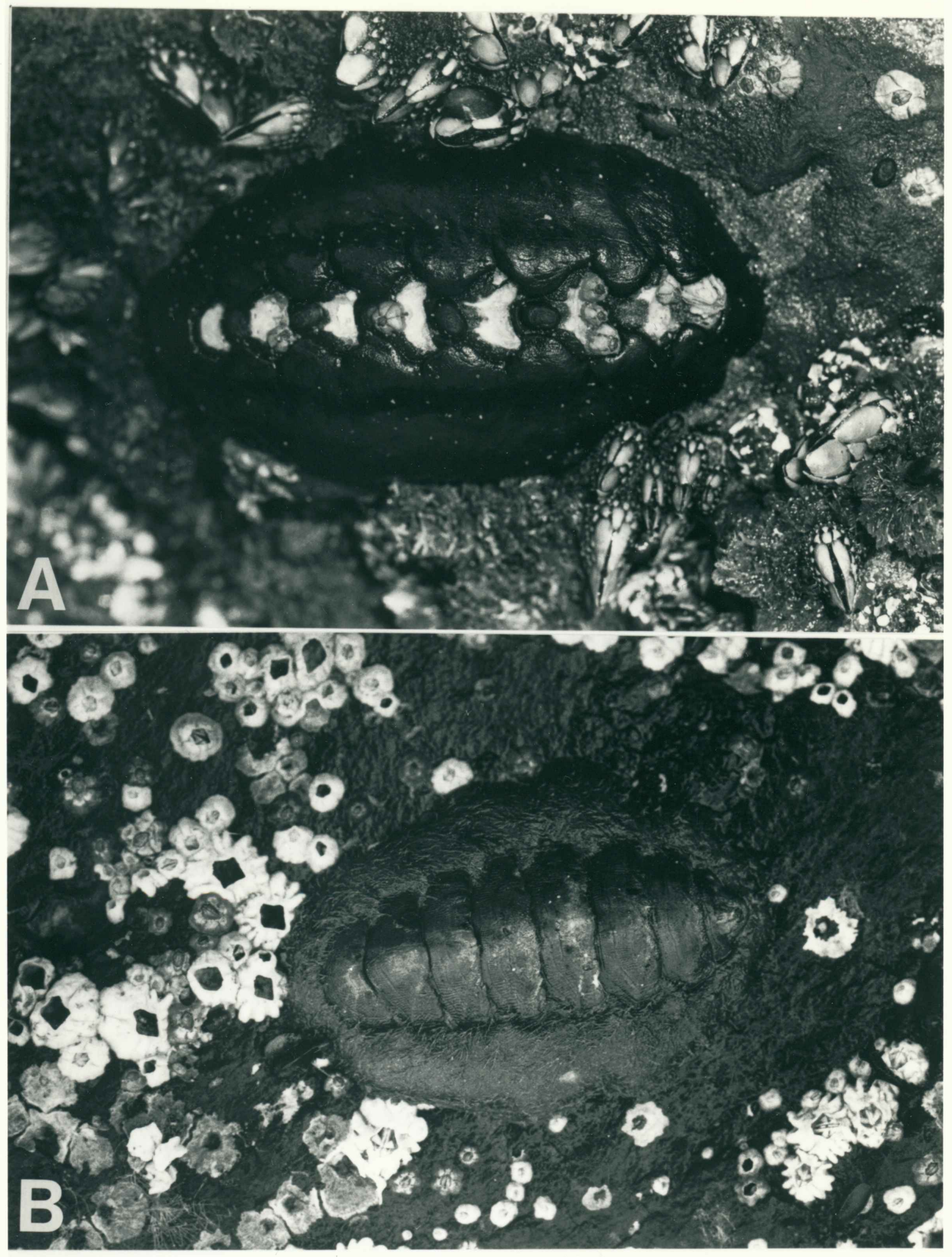

Figure 1. Adult specimens of Katharina tunicata (A) and Mopalia hindsii (B). 
Study Sites

An open coast and a brackish water study site were chosen for $\underline{\underline{K}}$. tunicata (Indian Beach, Ecola State Park) and M. hindsil (Garibaldi, Tillamook Bay) respectively. Site selection was based on salinity and temperature characteristics as well as common intertidal indicator species.

Indian Beach, Ecola State Park, Clatsop County, Oregon $\left(45^{\circ} 55^{\prime} \mathrm{N}\right.$ latitude) has a large rock and boulder outcropping at the south end of

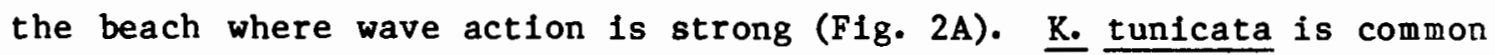
in this location with $\underline{M}_{*}$ hindsif and Tonicella lineata also present. Other common open coast organisms present are P1saster ochraceous, Mytilus californianus, Hemigrapsus nudus, and Pollicipes polymerus. Mean annual salinity is 29.06 ppt ( $85 \%$ seawater) and mean annual temperature is $12.4^{\circ} \mathrm{C}$ (Fig. 3, Seaside Aquarium Data; Bourke and Glenne, 1971).

Garibaldi, Tillamook Bay, Tillamook County, Oregon $\left(45^{\circ} 34^{\prime} \mathrm{N}\right.$ latitude) has a shale outcropping with small to large loose rocks at the north end of the bay with weak wave action (Fig. 2B). M. hindsii and $\underline{\text { M. }}$ muscosa are found under rocks and in crevices. Other common brackish water organisms present are Hemigrapsus oregonensis, Mytilus edulis, Pagurus spp., and Nucella emarginata. Mean annual salinity is 25.47 ppt (75\% seawater) and mean annual temperature is $10.9^{\circ} \mathrm{C}$ (Fig. 3, raw data from the State of Oregon, Department of Environmental Quality). 

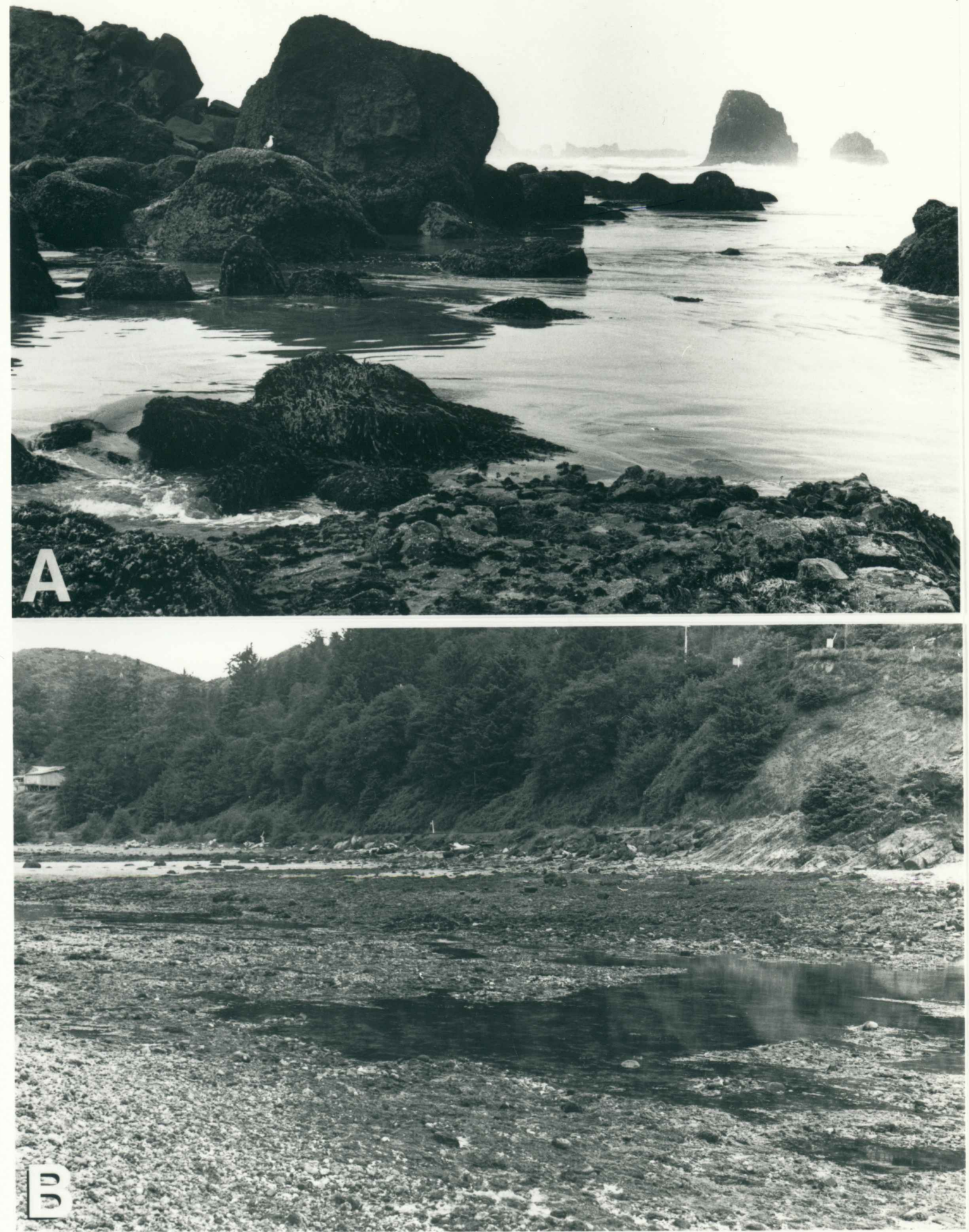

Figure 2. Indian Beach, Ecola State Park study site (A) and Garibaldi, Tillamook Bay study site (B) during low tide. 

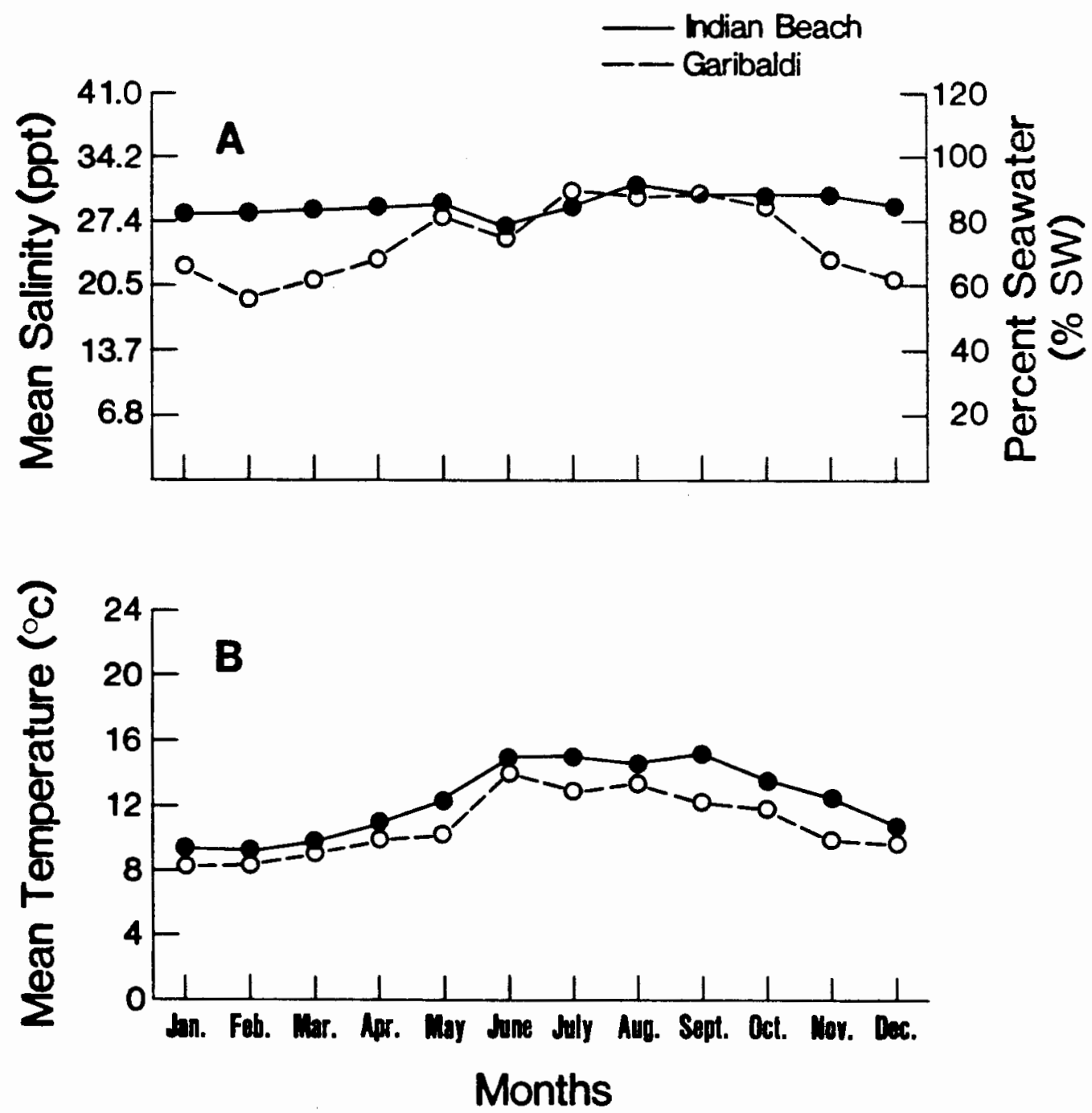

Figure 3. Mean monthly salinity (A, ppt) and mean monthly water temperature $\left(B,{ }^{\circ} \mathrm{C}\right)$ for Indian Beach and Garibaldi study sites. 
$\underline{\text { Osmotic Stress Tests }}$

Adult $\mathrm{K}_{0}$ tunicata (mean weight $=10.23$ grams) and $\underline{M_{0}}$ hindsil (mean weight $=10.90$ grams) were collected and acclimated to 34 ppt synthetic seawater ( $100 \%$ SW, Instant Ocean Synthetic Sea Salts, Aquarium Systems, Inc.) at $11^{\circ} \mathrm{C}$ and $16 \mathrm{~L}: 8 \mathrm{D}$ photoperiod for two weeks prior to testing. Eight animals of each species were subjected to a test salinity (120\%, $100 \%, 80 \%, 60 \%$, and $40 \% \mathrm{SW}$ ) for 36 hours in osmotic test apparatus (Fig. 4). Individual animals were held in separate chambers and monitored individually throughout the test. At time intervals of $0,1,2,4,6$, $8,12,24$, and 36 hours, animals were removed from chambers, blotted dry with absorbent towels, and then weighed using a Mettler PC 2200 scale. Animals were allowed 5 minutes to readhere in the chambers before being resubmerged in test salinity. Percent body weight changes due to osmotic stress gradient and volume regulation were calculated. Oxygen Consumption Tests

Oxygen consumption rates for four animals of each species were measured using a modified Scholander's respirometer (Scholander, 1950). Animals were monitored in test salinities $(120 \%, 100 \%, 80 \%, 60 \%$, and $40 \%$ SW) for 3-4 hours at $11^{\circ} \mathrm{C}$ and 16L:8D photoperiod following 48 hours of acclimation to the test salinity (normally post-osmotic stress testing). Oxygen consumption rates $(\mu 1 / \mathrm{g} / \mathrm{hr}$ ) were calculated for each species per salinity. 


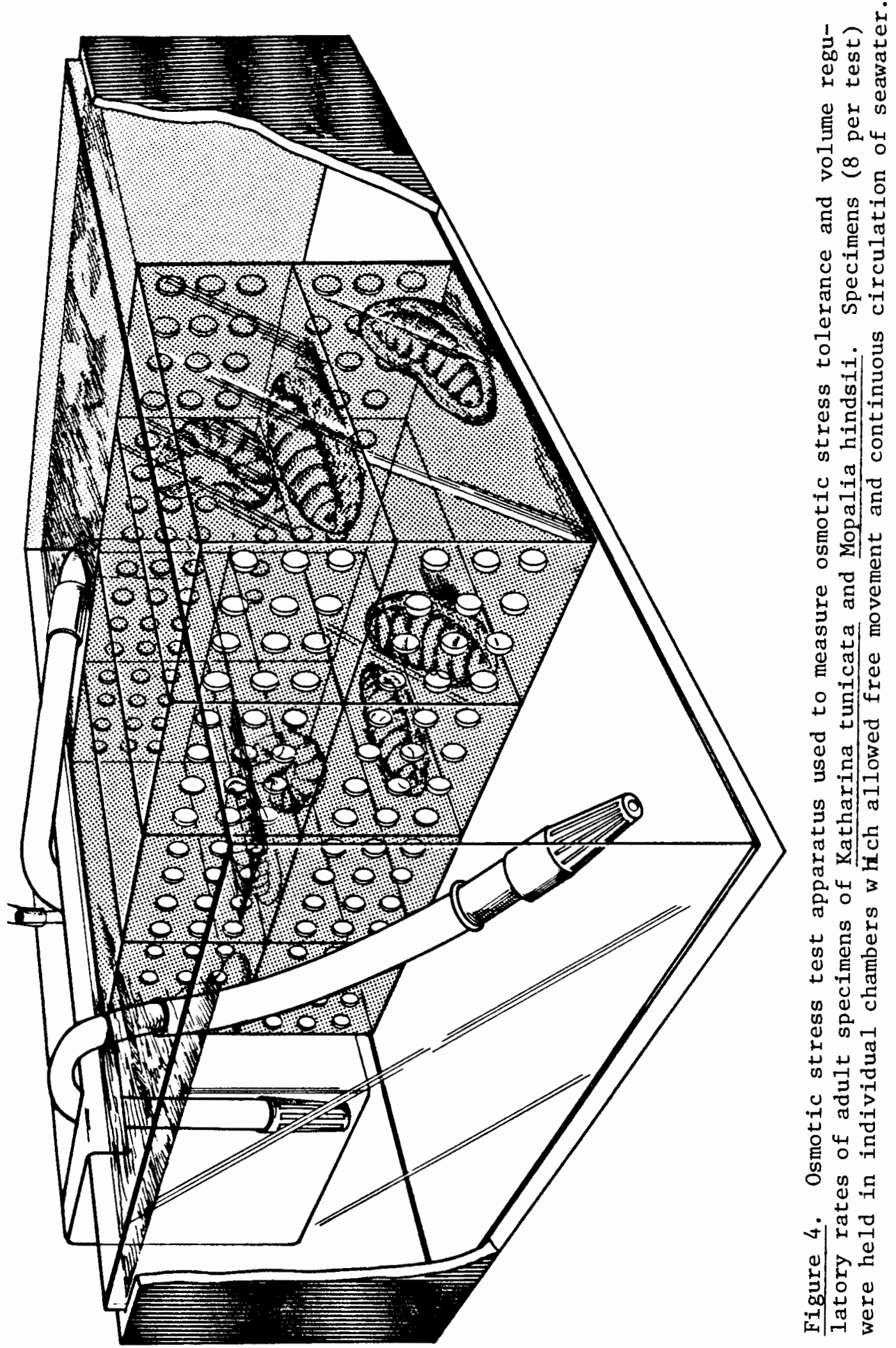


Morphological Comparisons

Radulae, ctenidia, and shape of the pallial groove were examined and compared using an AMR Model 1000 scanning electron microscope and an ISI-SS40 scanning electron microscope.

Specimens of $\underline{K_{0}} \underline{\text { tunicata }}$ and $\underline{M_{0}} \underline{\text { hindsil }}$ were anesthetized using an isotonic $\mathrm{MgCl}_{2}$ solution $\left(73 \mathrm{~g} / 1 \mathrm{DH}_{2} \mathrm{O}\right.$ ) for $1-2$ hours. Desired structures were dissected and prepared. Radulae were cleaned and rinsed with cacodylate buffer ( $\mathrm{pH} 7.4)$ in an ultrasonic cleaner and then allowed to air dry. Gill tissue and whole specimens were fixed in $6 \%$ glutaraldehyde at $4^{\circ} \mathrm{C}$ for one and four hours respectively (Bell et al., 1969). Specimens were then dehydrated through $25 \%, 50 \%, 70 \%, 95 \%$, and two changes of $100 \%$ ethanol. Gill tissue and whole specimens were freezefractured in $100 \%$ ethanol using liquid nitrogen in order to expose lamellar structure and pallial groove organization respectively (Humphreys et al., 1974). Next, specimens were flushed with liquid freon (50\% and 100\%) and then dried using an 0mar SPC - 900/EX Critica 1 Point Dryer. Specimens were mounted on stubs and coated with $200 \AA$ of gold using a Technics Sputter Coater.

Habitat Characteristics

Seawater samples were collected bimonthly at the two study sites during low tide from January 1985 to June 1985. Salinity (ppt) of seawater samples was determined using a YSI-33 Salinity-ConductivityTemperature (S-C-T) Meter. 
Dominant macroalgal species were collected from each study site and Identified (Smith, 1969; Guberlet, 1956). Macroalgal species present were compared with published diet preferences of the chitons (Steneck and Watling, 1982; Morris et al., 1980).

Statistical Analysis

Significant differences in osmotic stress response between $\underline{K}$.

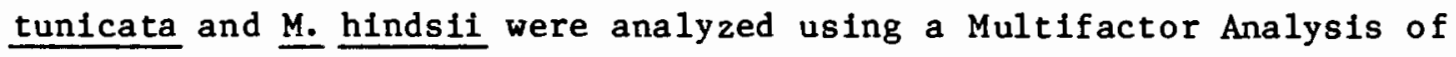
Variance (repeated measures; Winer, 1971). Significance level was $\mathrm{p}<$ 0.05

Significant differences in oxygen consumption rates between $\underline{k}$.

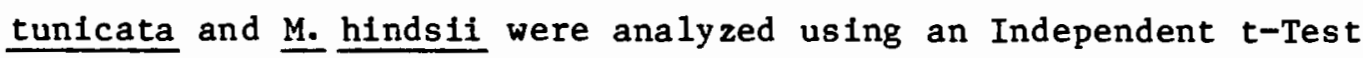
(Bruning and Kintz, 1977). Significant differences in oxygen consumption rates between salinities within each species were analyzed using an Analysis of Variance (completely randomized design; Bruning and Kintz, 1977). Significance level was $p<0.05$. 
CHAPTER III

\section{RESULTS}

\section{Osmotic Stress Tests}

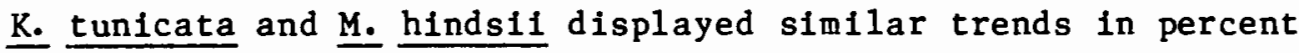
body weight (\% BW) variation and volume regulatory responses to osmotic stress (Fig. 5). However, K. tunicata experienced a significantly higher percent body weight increase than did M. hindsil in response to hypo-osmotic conditions $(80 \% \mathrm{sw}, \mathrm{df}=1,14, \mathrm{~F}=6.13, \mathrm{p}<0.05 ; 60 \% \mathrm{sw}$, $\mathrm{df}=1,14, \mathrm{~F}=16.85, \mathrm{p}<0.005 ; 40 \% \mathrm{SW}, \mathrm{df}=1,14, F=17.89, \mathrm{p}<$ 0.001). Following maximum percent body weight variation, both $\underline{\mathrm{K}}$.

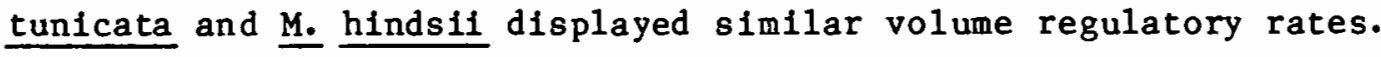
Maximum percent body weight variation was measured within 4 hours of exposure to $120 \%, 100 \%, 80 \%$, and $60 \%$ seawater (Table I). However, maximum percent body weight variation in $40 \%$ seawater was not reached until 24 hours following exposure (K. tunicata $=57.91 \pm 1.57 \% \mathrm{BW}$, $\underline{\text { M. }}$ hinds11 $=49.32 \pm 1.86 \% \mathrm{BW})$. Both species displayed reduced activity and adherence capabilities in $40 \%$ seawater compared with other salinities tested. 


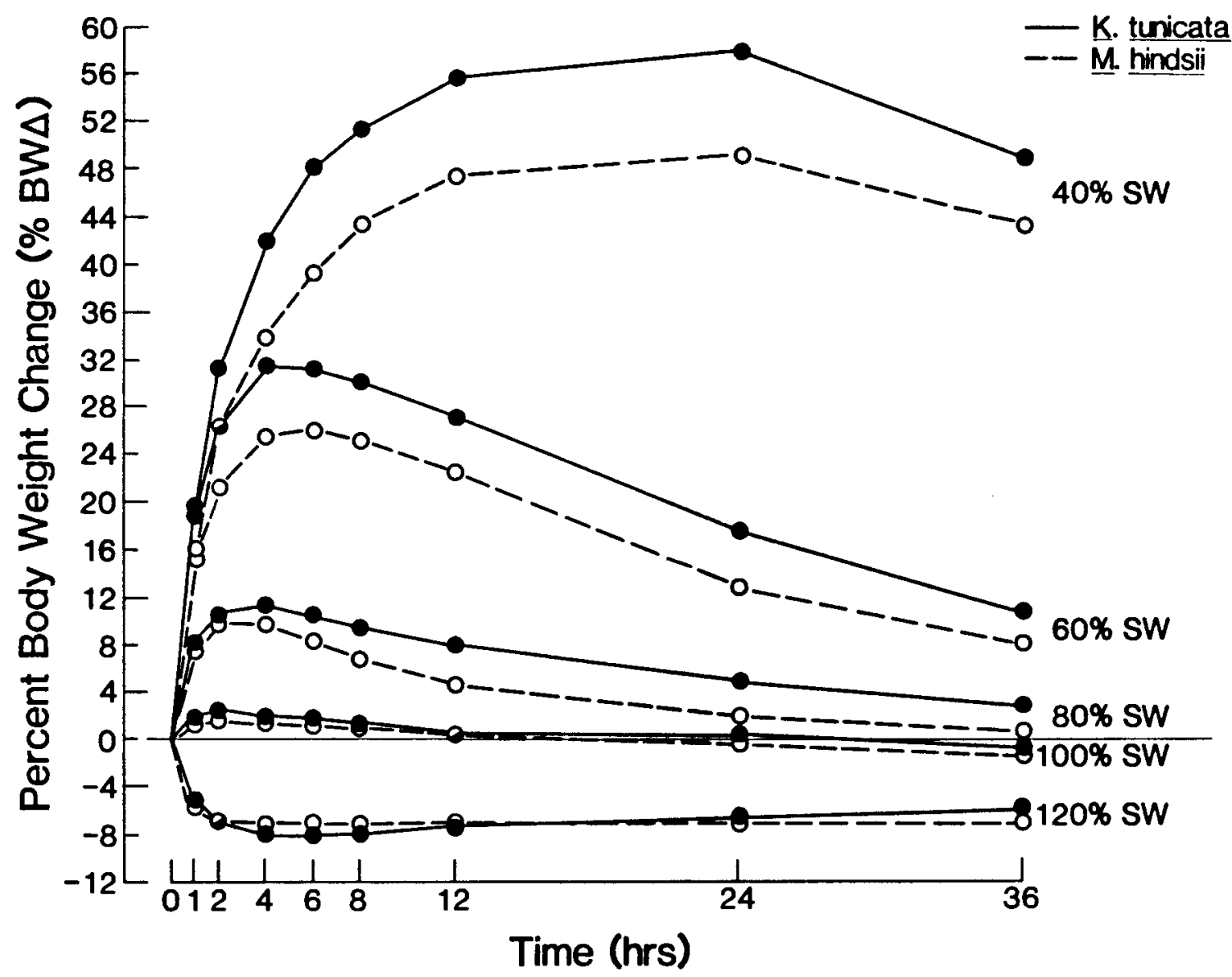

Figure 5. Mean percent body weight change ( $\%$ BW $\Delta$ ) and volume regulatory rates of adult specimens of Katharina tunicata and Mopalia hindsil in various test salinities over a 36 hour test period at $11^{\circ} \mathrm{C}$ and 16L:8D photoperiod. 
TABLE I

MAXIMUM PERCENT WEIGHT CHANGE FOR TWO OREGON CHITON SPECIES (Katharina tunicata AND Mopalia hindsii) IN VARIOUS SALINITIES

\begin{tabular}{rrr}
$\% \mathrm{SW}$ & $\underline{\text { K. }}$ tunicata & M. hindsi1 \\
\hline 120 & $-7.899 \pm 0.181(8)$ & $-7.165 \pm 0.248(8)$ \\
100 & $2.276 \pm 0.156(8)$ & $1.835 \pm 0.325(8)$ \\
80 & $11.456 \pm 0.402(8)$ & $10.000 \pm 0.527(8)$ \\
60 & $31.423 \pm 0.739(8)$ & $26.115 \pm 0.907(8)$ \\
40 & $57.906 \pm 1.573(8)$ & $49.321 \pm 1.864(8)$
\end{tabular}

Results are mean values \pm SE $(n)$.

Individuals tested in $40 \%$ seawater were held in test salinity for 5 days following standard test time to measure survival rates. Both species were able to volume regulate to pre-test range (‥ tunicata starting mean weight $\pm \mathrm{SE}=9.87 \pm 0.92$ grams, ending mean weight $\pm \mathrm{SE}=$

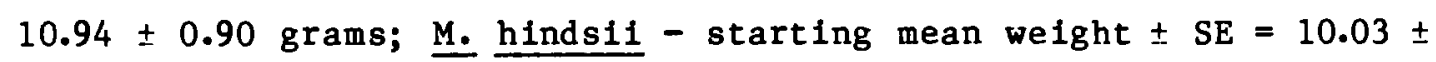
0.81 grams, ending mean weight $\pm \mathrm{SE}=10.12 \pm 0.81$ grams). All animals survived this period, however, $\underline{K}$. tunicata were inactive and adhered poorly to the holding tank sides. When returned to $100 \%$ seawater, $50 \%$ of the $\underline{K}$. tunicata specimens were unable to reacclimate and died, whereas $100 \%$ of the $\underline{\text { M. hindsii }}$ were able to reacclimate and survived. Results suggest that $40 \%$ seawater is below the ecological tolerance of both species, but M. hindsii appears to be more tolerant of the osmotic stress. 
Oxygen Consumption Tests

Oxygen consumption rates per salinity were not significantly dif-

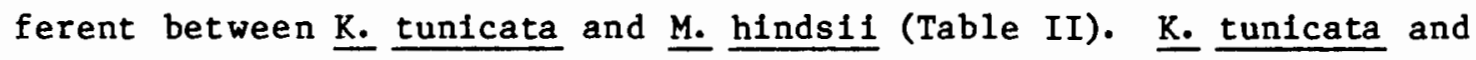
M. hindsif displayed simflar trends in response to salinity variation (Fig. 6). The mean rate of oxygen consumption by $\underline{K}$. tunicata was found to decrease significantly with the decrease in salinity to $40 \%$ seawater $(\mathrm{df}=4,14, \mathrm{~F}=3.24, \mathrm{p}<0.05)$. The mean rate of oxygen consumption by M. hindsif was also found to decrease similarly to $\underline{\underline{K} . ~ t u n i c a t a}$ in response to decrease in salinity to $40 \%$ seawater; however, the decrease observed for $\underline{M}$. hindsil was not found to be significant (df $=4,14, F=$ 0.88 , not sig.). The reduction in mean rates of oxygen consumption in $40 \%$ seawater by both $\underline{\mathrm{K}}$. tunicata and $\underline{\mathrm{M}}$. hindsil is similar to the trend in body weight variation and decrease in activity observed during osmotic stress tests.

TABLE II

OXYGEN CONSUMPTION RATES $(\mu 1 / \mathrm{g} / \mathrm{hr}$ ) FOR TWO OREGON CHITON SPECIES (Katharina tunicata AND Mopalia hindsii) IN VARIOUS SALINITIES

\begin{tabular}{rrr}
$\%$ SW & K. tunicata & M. hindsi1 \\
\hline 120 & $11.9 \pm 2.2(4)$ & $10.6 \pm 2.3(4)$ \\
100 & $13.5 \pm 1.3(4)$ & $12.7 \pm 1.2(3)$ \\
80 & $11.3 \pm 0.6(4)$ & $11.7 \pm 2.9(4)$ \\
60 & $10.6 \pm 1.7(4)$ & $12.4 \pm 2.7(4)$ \\
40 & $5.7 \pm 0.9(3)$ & $7.6 \pm 1.0(4)$
\end{tabular}

Results are mean $\pm S E(n)$ 


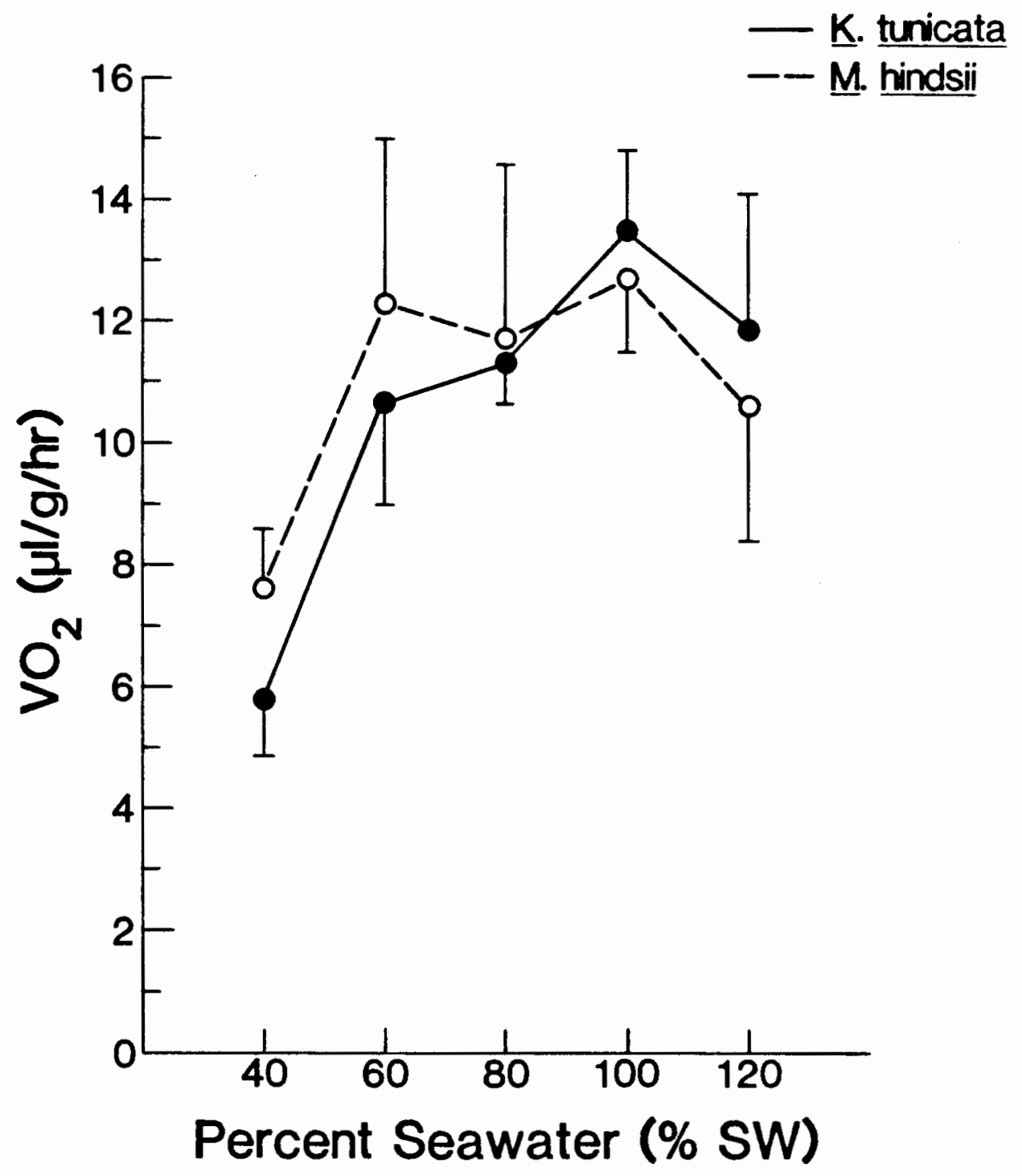

Figure 6. Mean oxygen consumption rates $\left(\mathrm{VO}_{2}\right)$ of adult specimens of Katharina tunicata and Mopalia hindsil in various test

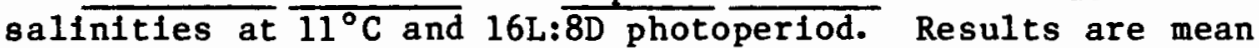
values $\pm S E$. 
Morphological Comparisons

Comparisons of radular morphology of $\underline{K_{\text {. }}}$ tunicata and $\underline{M}$. hindsil revealed on $1 y$ minor variations. Radulae of both species are comprised of seventeen teeth per row with major adaptation of the $1_{2}$ and $1_{5}$ teeth (Grassé, 1960) for grazing purposes (F1g. 7). The grazing teeth $\left(1_{2}\right.$ and $1_{5}$ ) of both species are similar in structure (Fig. 8). The primary difference observed between $\underline{K}$. tunicata and $\underline{M}$. hindsii is a variation $1 \mathrm{n}$ the anterior end of the median (m) teeth (Fig. 9).

Differences in ctenidial morphology between $\mathrm{K}_{0} \underline{\text { tunicata }}$ and $\underline{M}$. hindsii are related to differences in the shape of the pallial grooves of the two species. Ctenidia of $\mathrm{K}$. tunicata are rounded and blunt while those of $M_{.}$hindsii are more pointed and laterally flattened (FIg. 10). Ctenidial surfaces revealed no major interspecific differences in organization; both species possess a prominent lateral bands of cilia (Fig. 11; Hyman, 1967). The ctenidial lamellae of the two spectes have similar organization of vascular bed and respiratory epithelium comprised of a simple cuboidal to columnar epithelium (Fig. 12; Hyman, 1967)

The pallial groove of $\mathrm{K}$. tunicata differs from $\mathrm{M}_{\text {. hindsil in two }}$ aspects. The pallial groove of $\underline{\mathrm{K}}$. tunicata is taller with ctenidia suspended perpendicularly to the substrate. The pallial groove of M. hindsil is shallower and broader with gill ctenidia curved and suspended at an angle to the substrate (Figs. 13 and 14 ). 

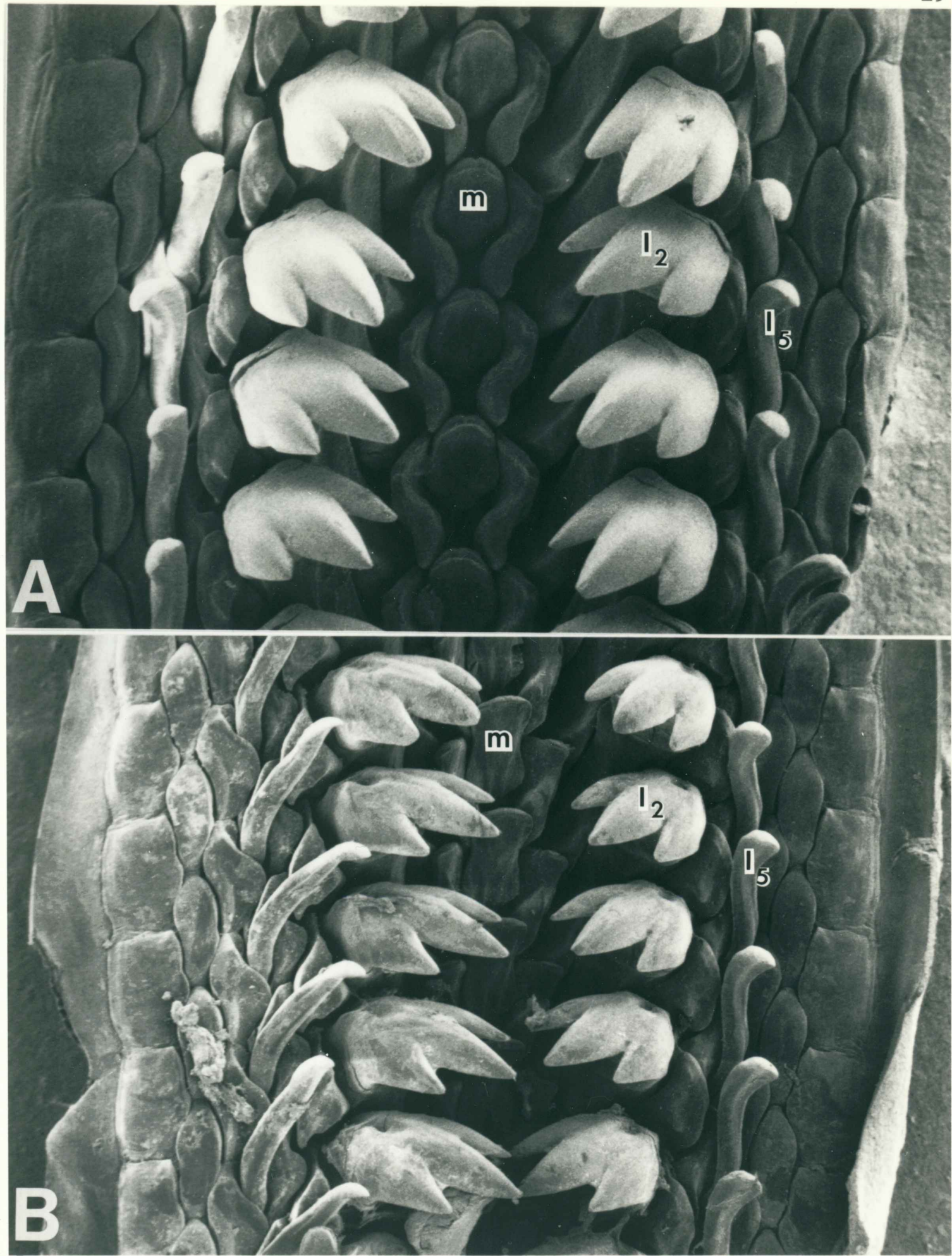

Figure 7. Radulae of Katharina tunicata (A, mag. $=78 \mathrm{X}$ ) and Mopalia hindsii $(B$, mag. $=53 \mathrm{X})$ revealing general organization plus grazing teeth $\left(1_{2}\right.$ and $\left.1_{5}\right)$ and median teeth $(\mathrm{m})$. 

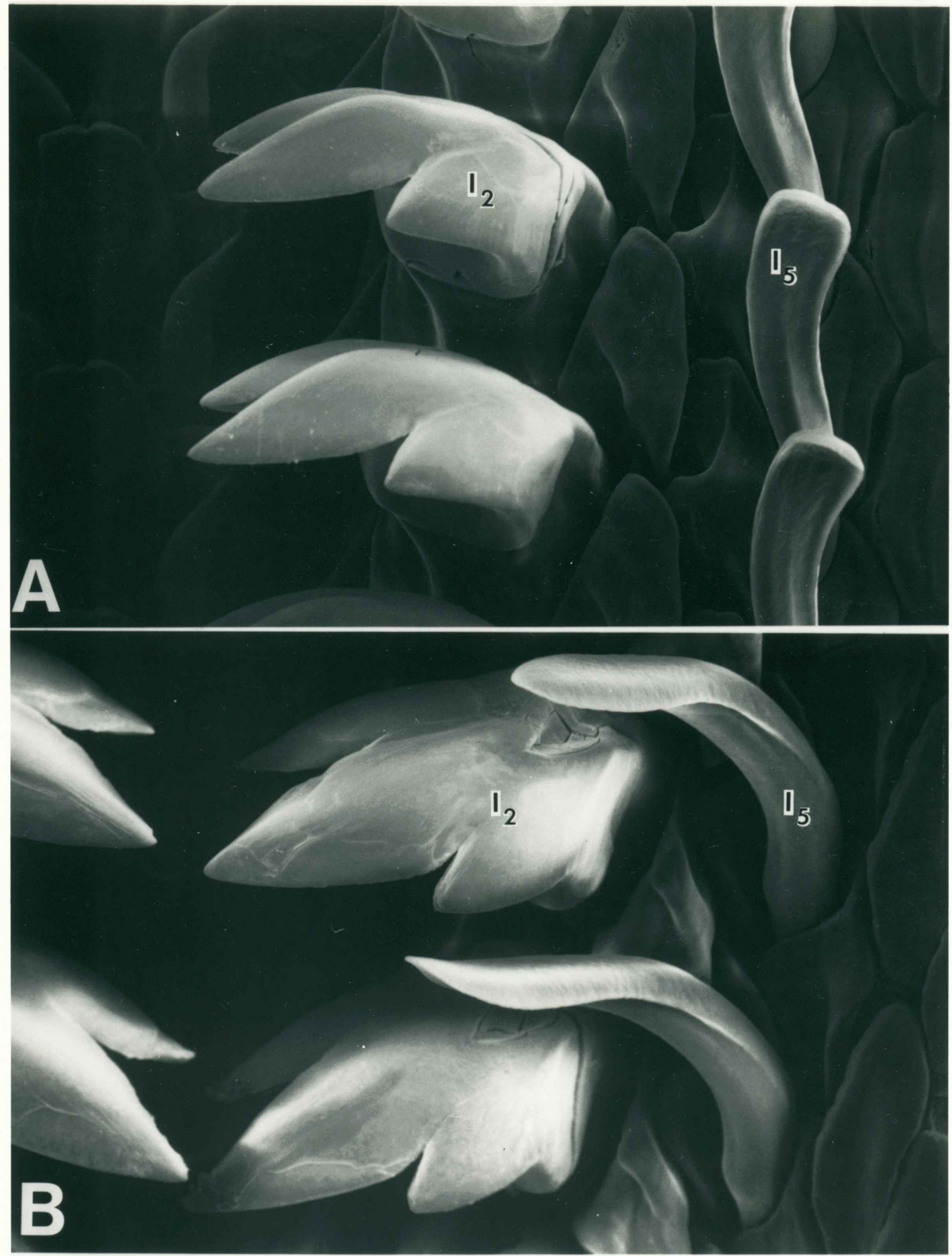

Figure 8. Grazing teeth (2nd latera1 $-1_{2}$, and 5 th lateral $-1_{5}$ ) from radulae of Katharina tunicata $(\mathrm{A}, \mathrm{mag} .=130 \mathrm{X})$ and Mopalia hindsii ( $\mathrm{B}, \mathrm{mag} \cdot=130 \mathrm{X}$ ). 

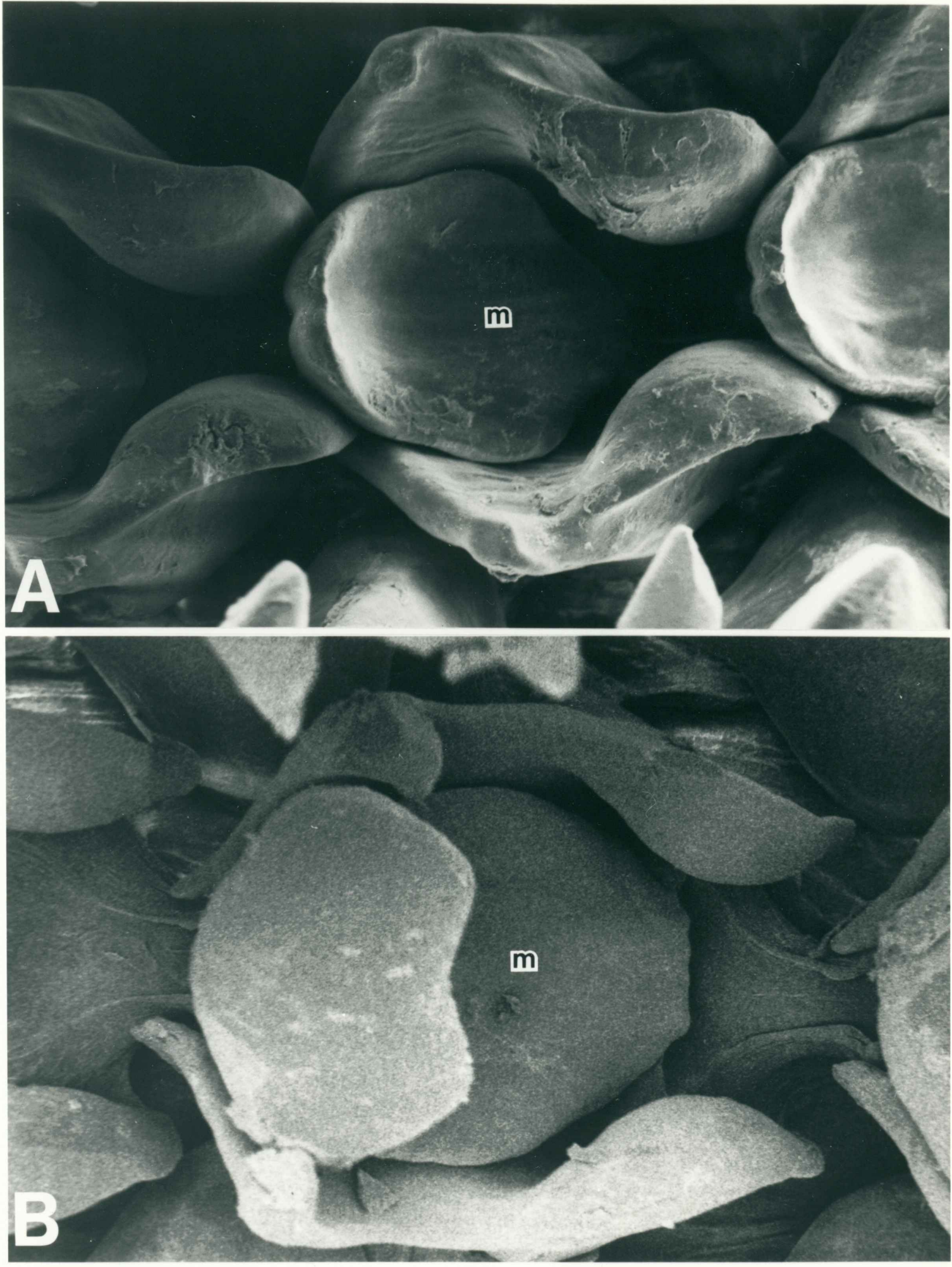

Figure 9. Median teeth (m) from radulae of Katharina tunicata (A, mag. $=322 \mathrm{X})$ and Mopalia hindsii $(B, \mathrm{mag} .=308 \mathrm{X})$ revealing the variation in the anterior tip. 

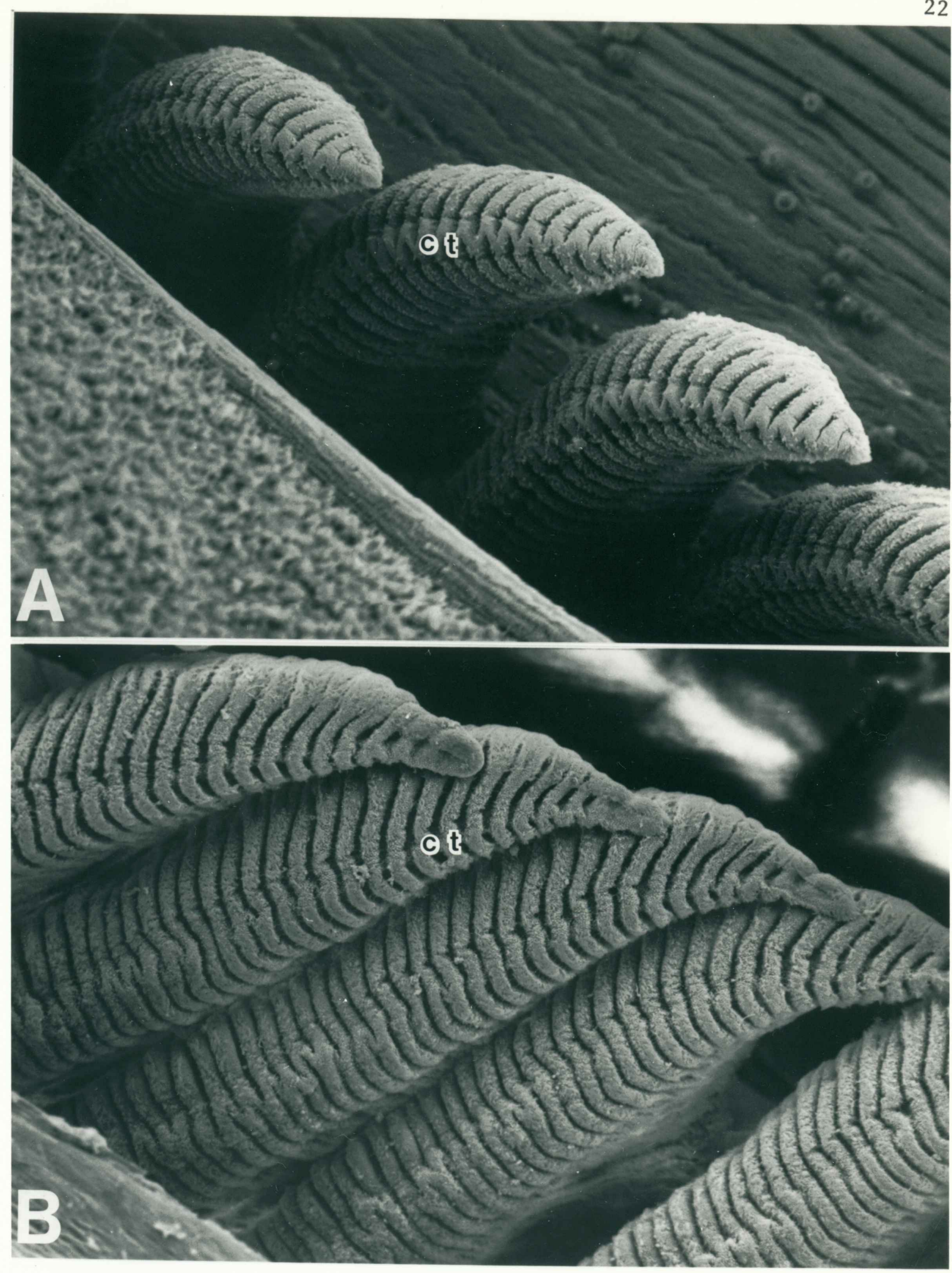

Figure 10. Ctenidia (ct) from Katharina tunicata (A, mag. $=113 \mathrm{X}$ )

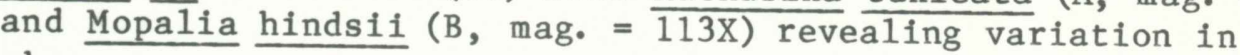
shape. 

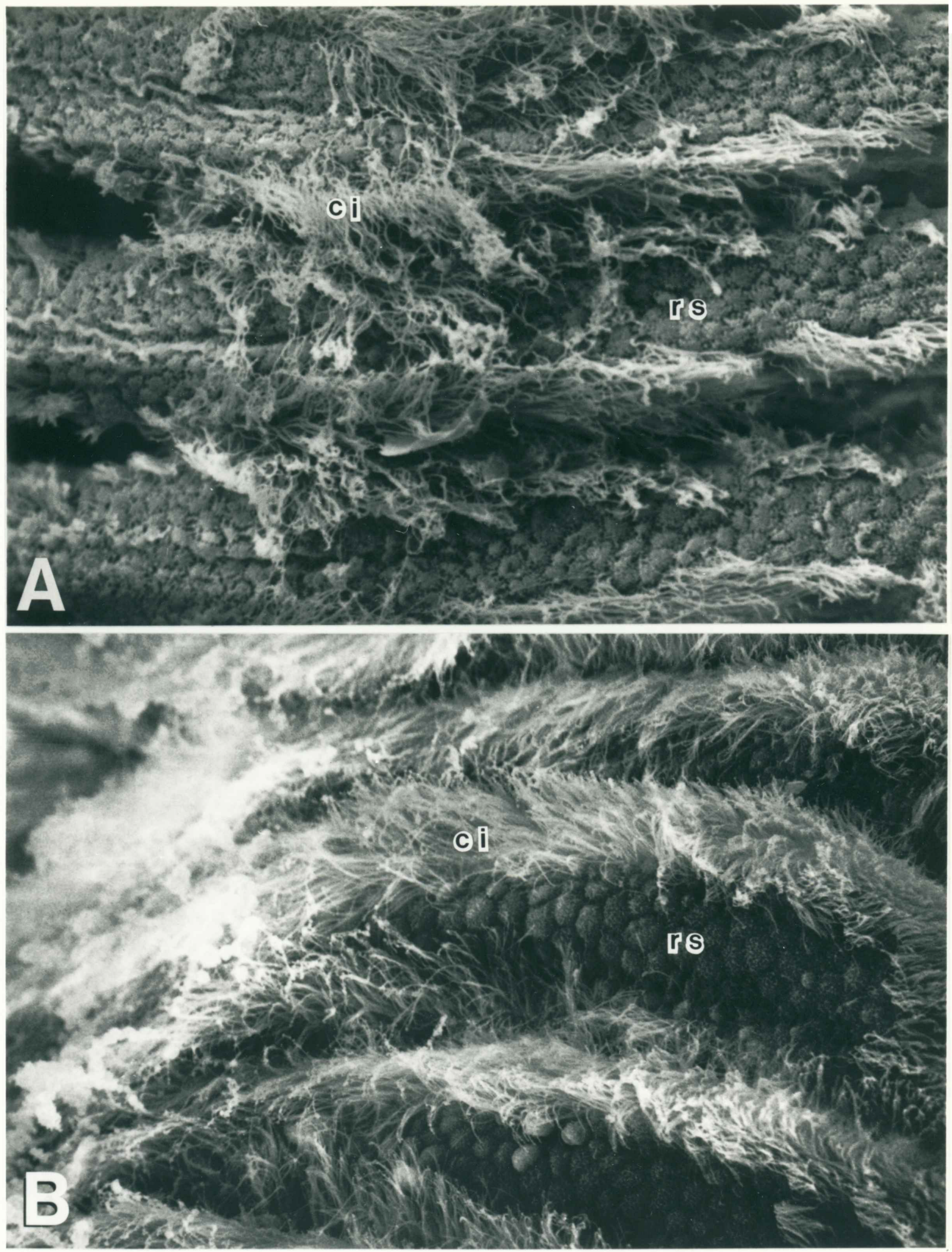

Figure 11. Surfaces of ctenidia from Katharina tunicata (A, mag. $=1100 \mathrm{X}$ ) and Mopalia hindsii (B, mag. = 1125X) revealing ciliation ( $c i$ ) and respiratory surface ( $r s$ ). 

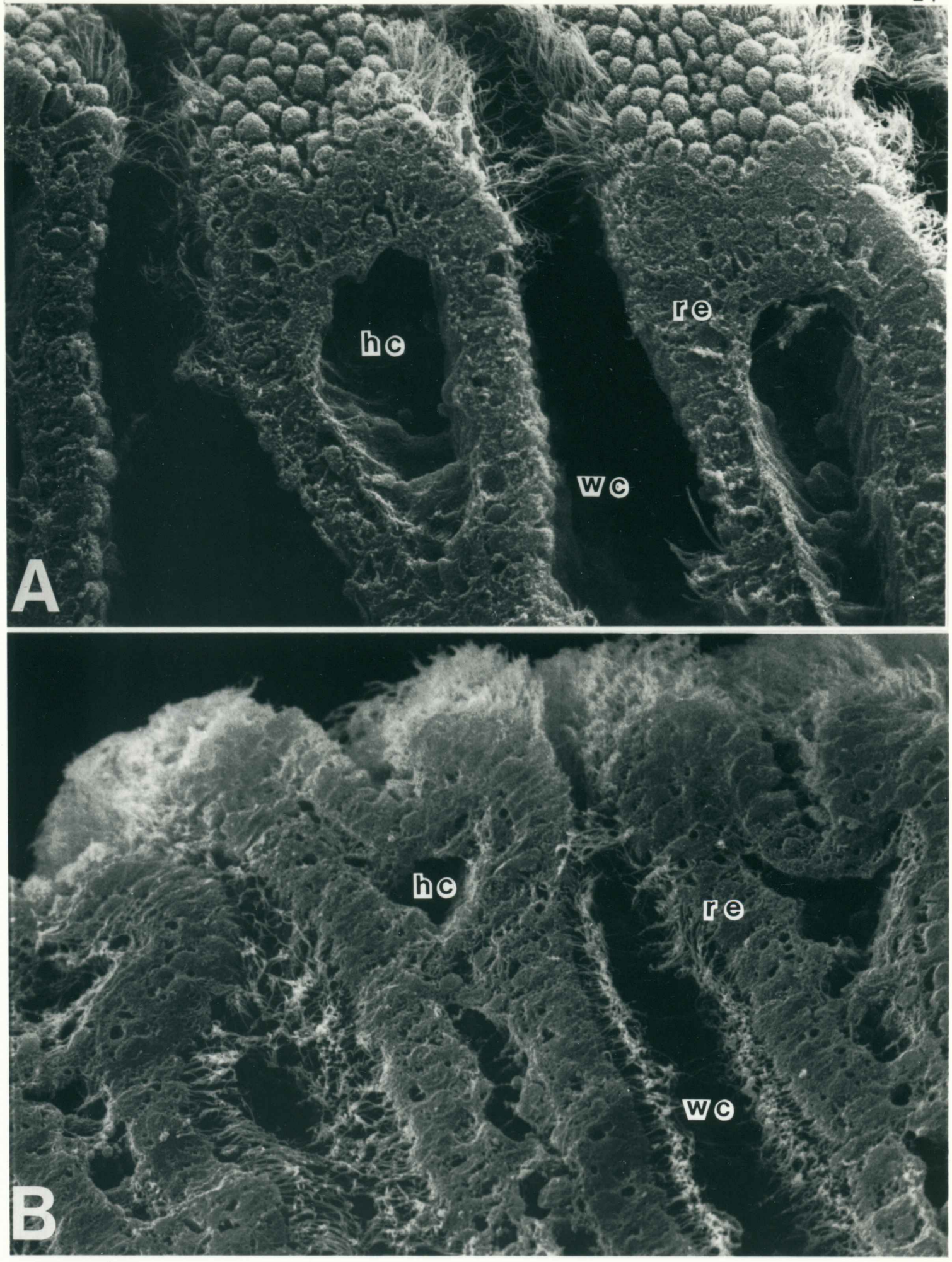

Figure 12. Lame1lar structure of ctenidia from Katharina tunicata $(\mathrm{A}$, mag. $=1400 \mathrm{X})$ and Mopalia hindsii $(\mathrm{B}, \mathrm{mag} .=1700 \mathrm{X})$ revealing the hemocoel (hc), respiratory epithelium (re), and interlamellar water channel (wc). 

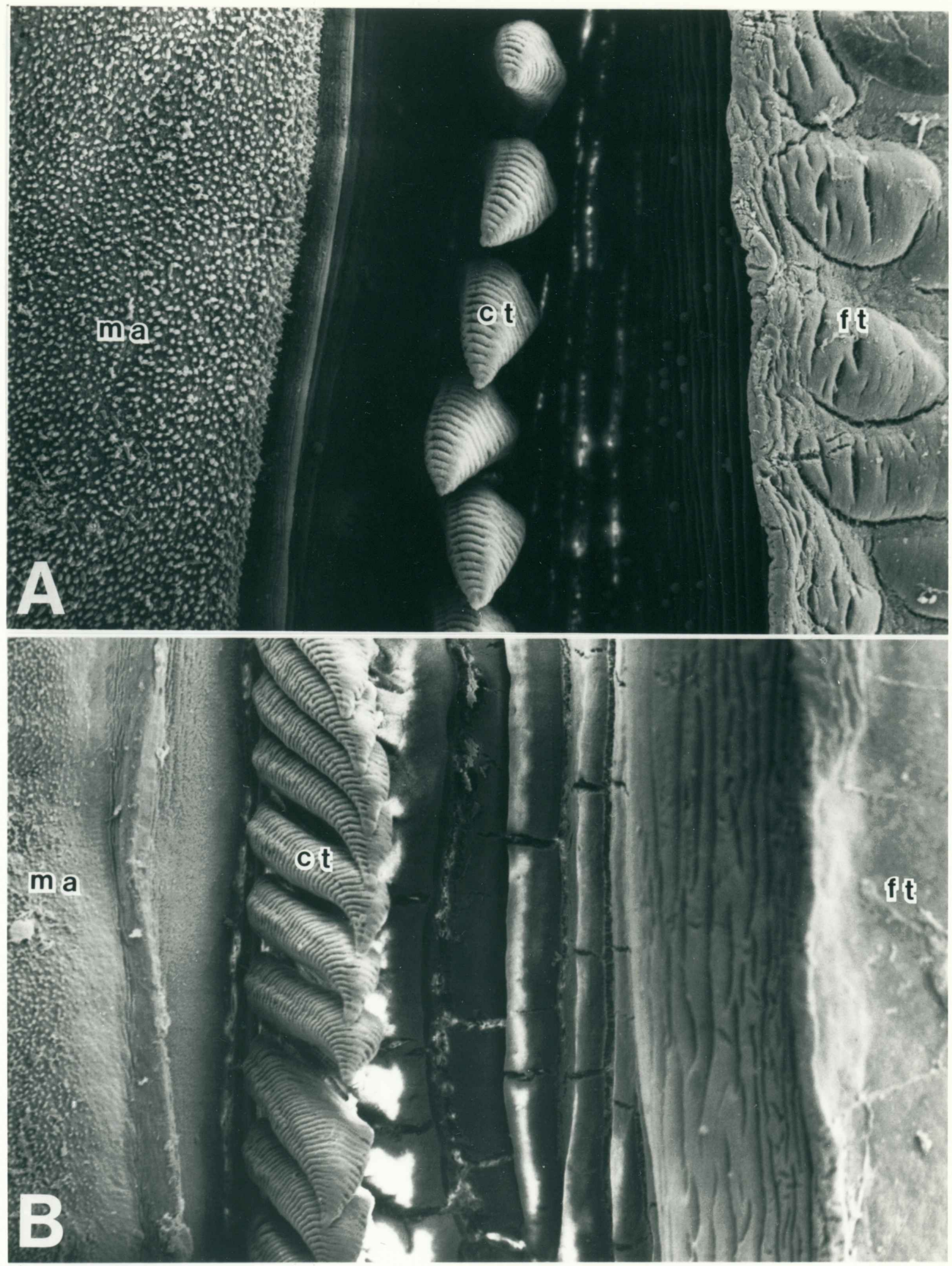

Figure 13. Pallial groove and ctenidia (ventral view) of Katharina tunicata $(\mathrm{A}, \mathrm{mag} .=53 \mathrm{X})$ and Mopalia hindsii $(\mathrm{B}$, mag. $=$ $28 \mathrm{X}$ ) revealing variation in shape of groove and orientation of ctenidia (ventral surface of mantle - ma, ctenidia - ct, and foot - $f t)$. 


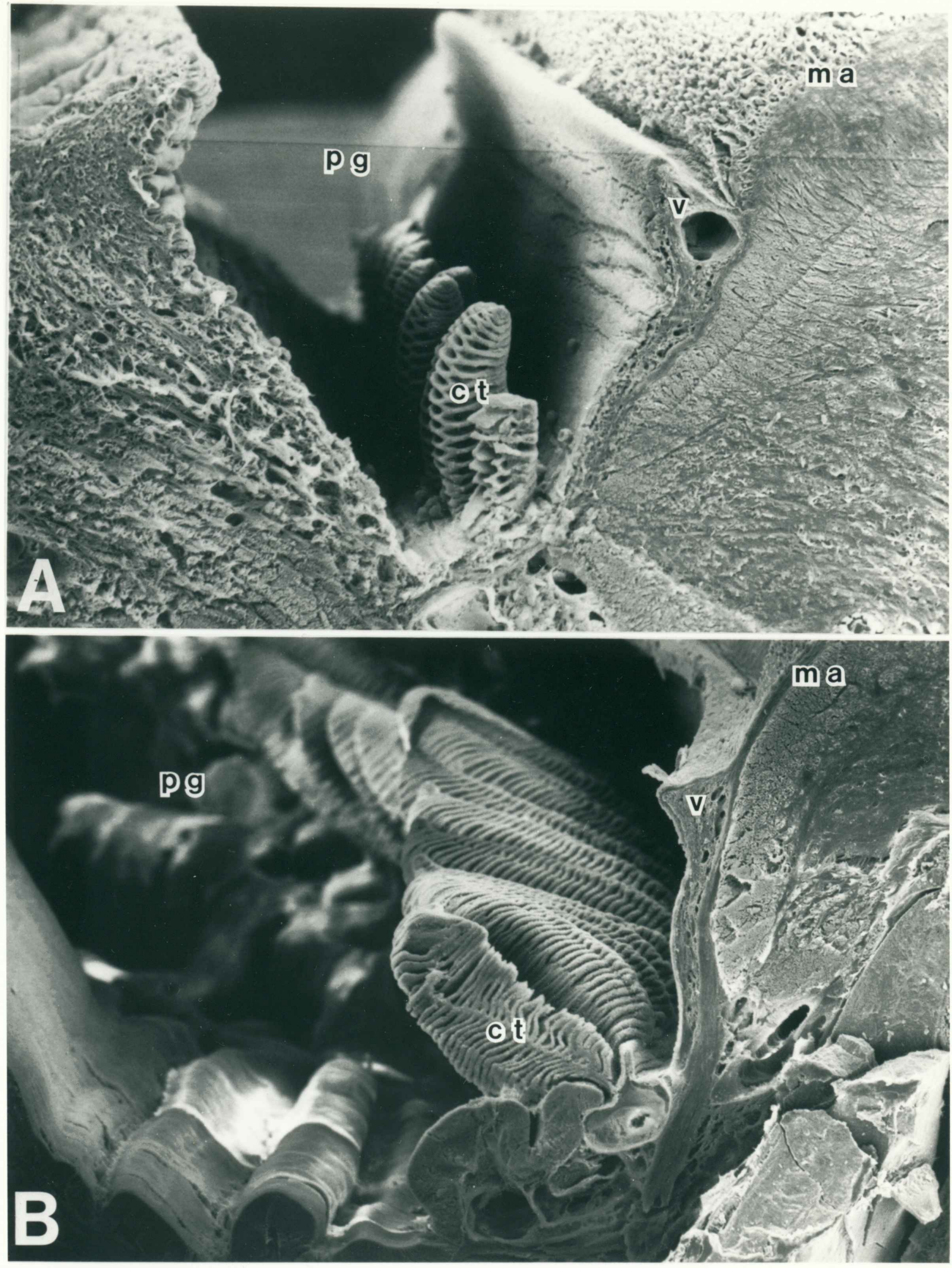

Figure 14. Pallial groove (X - section) and ctenidia of Katharina tunicata $(\mathrm{A}, \mathrm{mag} .=70 \mathrm{X})$ and Mopalia hindsii $(\mathrm{B}, \mathrm{mag} .=70 \mathrm{X})$ revealing variation in shape of pallial groove, mantle valve, and orientation of ctenidia (mantle - ma, mantle valve - v, ctenidia $c t$, and pallial groove - pg). 
Habitat Characteristics

Salinity measurements at low tide from January 1985 to June 1985 yielded a mean salinity of $25.63 \pm 0.85 \mathrm{ppt}(75 \%$ seawater $)$ for the Indian Beach study site and a mean salinity of $21.04 \pm 1.05$ ppt (63\% seawater) for the Garibaldi study site. During Apri1 1985, there was an overlap in the salinities of the study sites. However, Garibaldi consistently reached lower extremes in salinity (February $=19.2 \mathrm{ppt}$, April $=16.7$ ppt, and June $=15.5$ ppt) than Indian Beach (Apri1 $=20.8$ ppt; Fig. 15). Although mean salinities during the study were found to be lower than mean annual salinities for study sites (Indian Beach = $29.06 \mathrm{ppt}$, Garibaldi $=25.47 \mathrm{ppt}$ ), the variation in mean salinities between study sites during the study ( $4.59 \mathrm{ppt,} 12 \%$ seawater) parallels the variation in mean annual salinities ( 3.59 ppt, $10 \%$ seawater). Measurements were taken primarily during the winter months when freshwater runoff from coastal land is greatest.

Identification of dominant macroalgal species revealed variation between the Indian Beach site (six Rhodophyta, three Phaeophyta) and the Garibaldi site (four Rhodophyta, three Phaeophyta, and one Chlorophyta) in species present (Table III). Three macro-algal species (Laminaria setche11i, Fucus distichus, and Iridaea cordata) were common to both study sites. The coralline algae (crustose coralline alga and Bossiella orbigniana), Gymnogongrus 1inearis, Plocamium oregonum, Prionitis

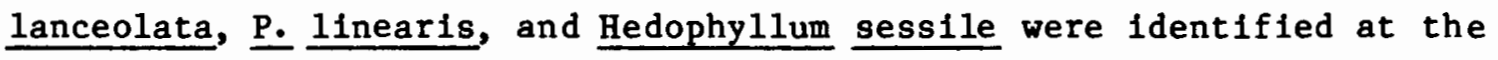
Indian Beach site only. Hedophyllum sessile is reported as a major dietary constituent of $\mathrm{K}$. tunicata (Steneck and Watling, 1982). Gigartina exasperata, G. volans, Gracilaria verrucosa, Halosaccion 
glandiforme, and Ulva taeniata are common to the Garibaldi site.

Gigartina spp. as well as animal material are reported as common

dietary constituents of Mopalla spp. (Steneck and Watling, 1982; Morris et al., 1980). 


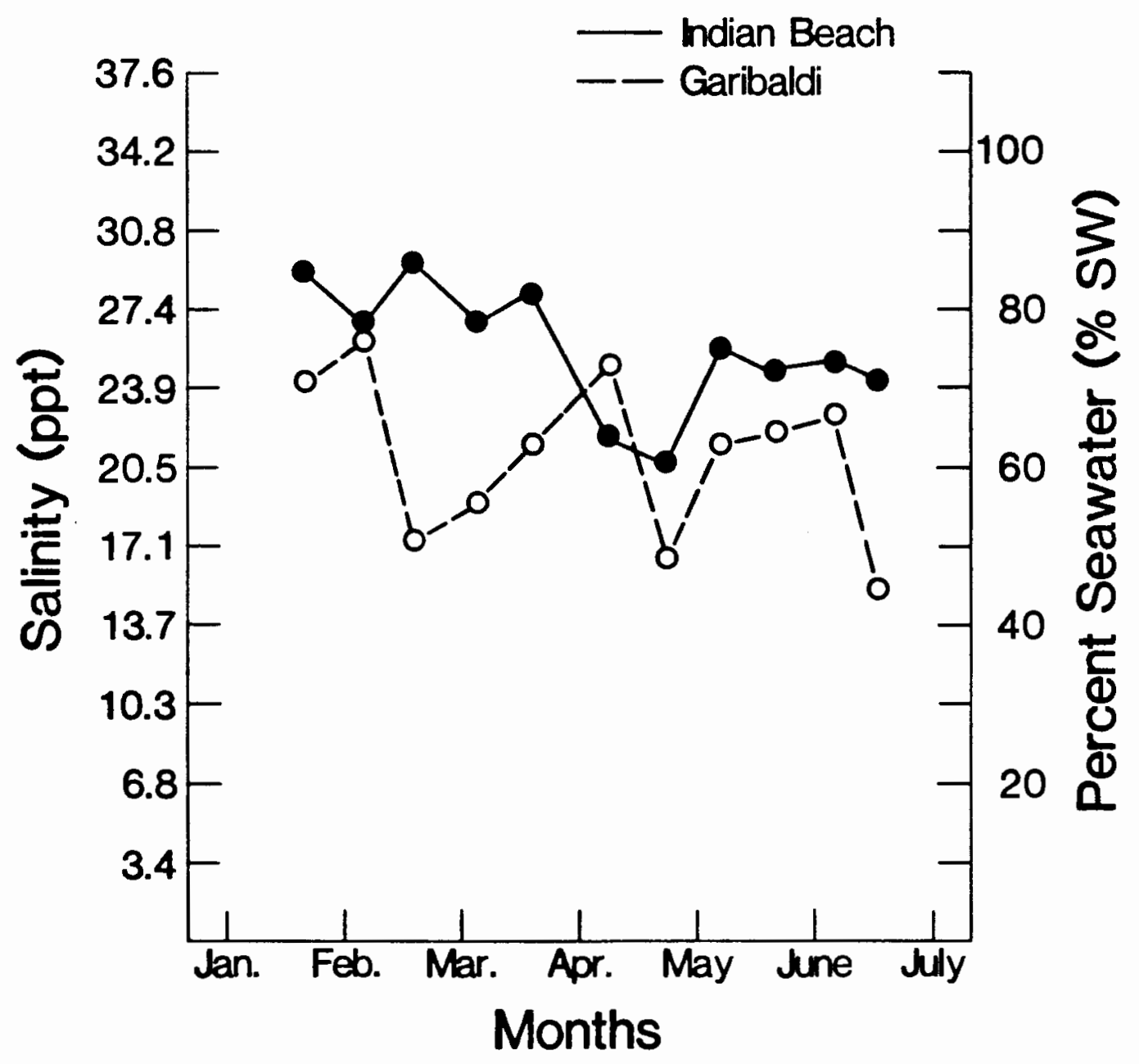

Figure 15. Bimonthly salinity measurements during low tide from January 1985 to June 1985 for Indian Beach and Garibaldi study sites. 
TABLE III

DOMINANT MACROALGAL SPECIES OF INDIAN BEACH, ECOLA STATE PARK STUDY SITE AND GARIBALDI, TILLAMOOK BAY STUDY SITE

Macroalgal Species

Rhodophyta

Crustose Coralline Alga

Bossiella orbigniana

Gigartina exasperata

Gigartina volans

Gracilaria verrucosa

Gymnogongrus Iinearis

Iridaea cordata

Plocamium oregonum

Prionitis 1anceolata

Prionitis linearis

Phaeophyta

Fucus distichus

Halosaccion glandiforme

Hedophy11um sessile

Laminaria setche111

Chlorophyta

U1va taeniata
Indian Beach

Garibaldi

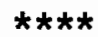

$\star \star \star *$

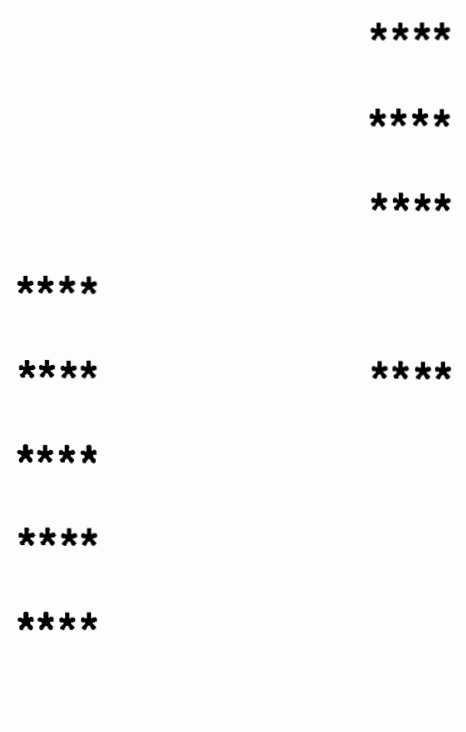

$\star \star \star \star$

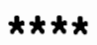

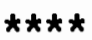

$\star \star \star \star$

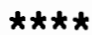

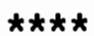

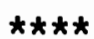




\section{CHAPTER IV}

\section{DISCUSSION}

Variation in habitat selection by marine chitons is thought to be Influenced by salinity. However the influence of salinity on the physiology and ecology of chitons has recelved limilted attention. Boyle (1969) reported that $\underline{S}$. pelliserpentis is exposed to salinity fluctuations of $40 \%$ (14 ppt) to $130 \%$ (45 ppt) seawater for short periods of time. Stickle and Denoux (1976) observed that in many marine invertebrates, including K. tunicata, hemolymph osmoconcentrations fluctuate with tidal fluctuation but do not vary during exposure to air.

The influence of salinity on variation in habitat selection of $K_{\text {. }}$ $\underline{\text { tunicata }}$ and $\underline{M_{0}} \underline{\text { hindsif }}$ appears to be minimal. Although $\underline{K_{0}} \underline{\text { tunicata }}$ displayed significantly higher variation in percent body weight than did M. hindsii in response to hypotonic stress conditions $(80 \%, 60 \%$, and $40 \%$ SW), both species displayed similar rates of weight gain and volume regulation in all salinities tested. Both species, however, experienced drastically increased weight gain in response to $40 \%$ seawater compared with other salinities tested. The percent weight changes observed for

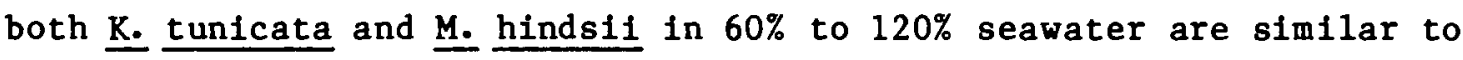
those reported by McGill (1976) for C. hartwegil in 75\% to $125 \%$ seawater. Boyle (1969) tested the osmotic stress tolerance of $\underline{S}$. pelliserpentis in $0 \%$ to $150 \%$ seawater and found that species tolerant of salinity ranging from $50 \%$ to $150 \%$ seawater. 
However, the response of $\mathrm{S}$. pelliserpentis to $50 \%$ seawater was similar to that observed for $\mathrm{K}$. tunicata and $\underline{M_{0}}$ hindsi1 in $40 \%$ seawater. The results support the hypothesis that $\underline{K}_{0} \underline{\text { tunicata }}$ and $\underline{M_{0}}$ hindsif are osmoconformers with volume regulatory capactites and are simflar in osmotic stress tolerance to S. pelliserpentis, C. hartwegil, and N. californica (Boyle, 1969; McG111, 1976; and S1monsen, 1976).

Lebsack (1976) reported that deviation in salinity from normal seawater results in a decrease in oxygen consumption rate by Mopalia 1ignosa, although the salinities Lebsack tested ranged only from $90 \%$ to $120 \%$ seawater. Oxygen consumption rates for $\mathrm{K}_{-}$tunicata were observed to decrease significantly in response to salinity variation from $100 \%$

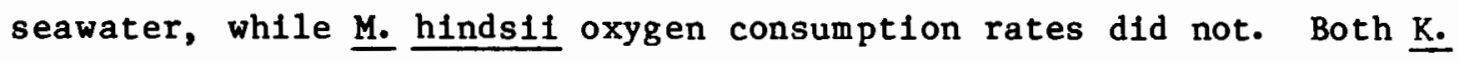

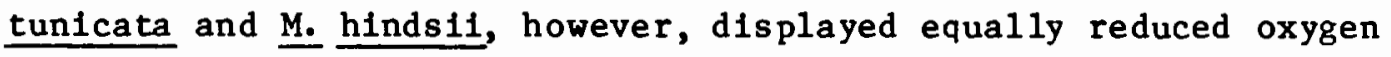
consumption rates in response to $40 \%$ seawater. This reduction in oxygen consumption in $40 \%$ seawater parallels the increased weight gain observed in the osmotic stress tolerance results.

Stickle and Ahokas (1975) suggested that Mopalia muscosa may be more resistant to osmotic stress than 1 s $\underline{\mathrm{K}}$. tunicata because $\underline{\text { M. }}$ muscosa may be able to isolate its pallial groove and ctenidia from the external medium more effectively than can $\underline{K}_{*} \underline{\text { tunicata. }} \underline{M_{0}} \underline{\text { muscosa }}$ and $\underline{M_{\bullet}} \underline{\text { hindsil }}$ overlap in distribution and both are common in the Garibaldi study site. The two species are morphologically similar, differing primarily in the dorsal surface of the mantles. Comparison of the shape of the pallial groove, mantle valve size, and ventral surface of the mantles of $\underline{K_{*}} \underline{\text { tunicata }}$ and $\underline{M}_{0}$ hindsi1, however, suggested no significant variation between these two species in their ability to isolate the pallial groove 
and ctenidia. The differences observed in the shape of the pallial groove and ctenidia reflect differences in general body morphology which correlate more directly with micro-habitat preferences than differences observed in habitat selection of these species.

The variation in mean salinity (4.59 ppt, $12 \% \mathrm{sW}$ ) observed between the Indian Beach and Garibaldi study sites from January 1985 to June 1985 is within the physiological tolerances of both $K_{0}$ tunicata and $\underline{\text { M. }}$ hindsii. The increase in body weights and decrease in oxygen consumption rates of $\underline{K}$. tunicata and $\underline{M_{0}}$ hindsil in $40 \%$ seawater dilution, and their reduced adherence capabilitles suggests that this salinity is near or below the ecological tolerances of both species even though it is physiologically tolerable under laboratory conditions. Salinities bel ow $40 \%$ seawater were not measured for either study site. Although $\mathrm{K}$. tunicata is capable of tolerating $40 \%$ seawater for a limited period, the data suggest that $\underline{M}$. hindsi1 may be more tolerant of this extreme dilution. Boyle (1969) reported that S. pelliserpentis could survive dilution to $50 \%$ seawater for at least 24 hours. Simonsen (1976) suggested that long term acclimation to variation in salinity may influence osmotic stress tolerance in N. californica. Thus, acclimation may account in part for the observed variation in osmotic tolerance to extreme dilution (40\% SW) between $\mathrm{K}_{\text {. tunicata }}$ and $\mathrm{M}_{0}$ hInds11.

The diet preferences of $\underline{K_{0}}$ tunicata and $\underline{M}$. hindsil may influence the difference observed in habitat selection. Hedophyllum sessile, a major dietary constituent of $\underline{K_{0}}$ tunicata, is restricted to open coast habitats such as the Indian Beach site (Himmelman, 1978; Steneck and Wat1Ing, 1982). Several Glgartina spp. plus anlmal material, major 
dietary constituents of $\underline{M} . \underline{h i n d s i 1}$, are less restricted and are common at the Garibaldi site (Morris et al., 1980; Steneck and Wat1ing, 1982). Comparison of radular morphology and structure of grazing teeth $\left(1_{2}\right.$ and ${ }_{15}$ ), however, revealed no clear difference between $\underline{K}$. tunicata and $\underline{M}$. hindsil related to adaptation to different diets. Radular morphology of both these species support the "multi-purpose tool" description of Steneck and Watling (1982).

Boyle (1969) suggested, "that microhabitat osmotic fluctuations are unlikely to limit the distribution of s. pelliserpentis", due to its euryhaline characteristics. The data support a similar conclusion for $\underline{K}$. tunicata and $\underline{\text { t. hindsif }}$ in that both are euryhaline in character and display similar physiological capabilities.

Although salinity may not influence the difference in habitat

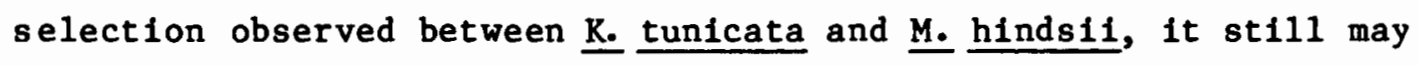
influence habitat selection in two ways: 1) the tolerance to osmotic stress of larval stages may vary significantly; and 2) the influence of salinity on macroalgal species may affect the settling responses of veliger stage. Barnes and Gonor (1973) reported that $\underline{T}$. 11neata larvae display a selective settling response to crustose coralline algae, Lithothamnium and Lithophyllum spp.

In conclusion, these results suggest that other factors are involved in the difference in habitat selection between $\underline{K}$. tunicata and $M_{0}$ $\underline{\text { hindsil, }}$ and that chitons display a high level of phystological plasticity. 
1. Katharina tunicata and Mopalia hinds11 are osmoconformers in salinities ranging from $40 \%$ (13.7 ppt) to $120 \%$ ( $41.0 \mathrm{ppt})$ seawater with equivalent volume regulatory capabilities.

2. Both spectes showed reduced oxygen consumption rates and significantly increased weight gain in $40 \%$ seawater.

3. SEM comparisons of radulae, ctenidia, and shape of the pallial groove revealed no significant differences between the species relevant to differences observed in habitat selection.

4. Variation in dominant macroalgal species between study sites reflected published dietary preferences; $\underline{K}$. tunicata feeds on Hedophyllum sessile, while M. hindsit feeds on Gigartina spp. and animal material.

5. Salinity does not appear to be a major influence on habitat selection in chitons within the intertidal zone. 


\section{BIBLIOGRAPHY}

Andrus, J. K., and Legard, W. B. (1976) Description of habitats of several intertidal chitons found along the Monterey Peninsula of central California. Veliger 18, Supplement, 3-8.

Barnes, J. R., and Gonor, J. J. (1973) The larval settling response of the lined chiton Tonicella lineata. Marine Biology 20, 259-264.

Be11, A. L., Barnes, S. N., and Anderson, K. L. (1969) A fixative technique for electron microscopy which provides uniform $1 y$ good preservation of the tissues of a variety of marine invertebrates. Biological Bulletin 137, 393.

Bourke, R. H., and Glenne, B. (1971) The Nearshore Physical Oceanographic Environment of the Pacific Northwest Coast. Reference $71-45$, Department of Oceanography, Oregon State University, Corvallis, Oregon.

Boyle, P. R. (1969) The survival of osmotic stress by Sypharochiton pelliserpentis (Mollusca: Polyplacophora). Biological Bulletin $136,154-166$.

Bruning, J. Lo, and Kintz, B. Io (1977) Computational Handbook of Statistics. Scott, Foresman and Co., Glenview, Illinois.

Burton, R. F. (1983) Ionic regulation and water balance. In: A. S. M. Saleuddin and R. M. Wilbur (eds.), The Mollusca, Vol. 5, Physiology 2. Academic Press, New York.

Chelazz1, G., Focard1, S., and Denenbourg, J. L. (1983) A comparative study on the movement patterns of two sympatric tropical chitons (Mollusca: Polyplacophora). Marine Biology 74, 115-125.

Dayton, P. K. (1975) Experimental evaluation of ecological dominance in a rocky intertidal algal community. Ecological Monograph 45, 137159.

Gómez, R. L. (1976) An association between Nuttallina californica and Cyanoplax hartwegil, two west coast polyplacophora (chitons). Veliger 18, Supplement, 28-29.

Grassé, P. (1960) Traite De Zoologie V. Libraires de 1'Academie de Médecine, Paris (Masson et Cle, ed.).

Guberlet, M. L. (1956) Seaweeds at Ebb Tide. University of Washington Press, Seattle. 
Himmelman, J. H. (1978) The reproductive cycle of Katharina tunicata Wood and its controlling factors. Journal of Experimental Marine Biology and Ecology 31, 27-41.

Humphreys, W. J., Spurlock, B. O., and Johnson, J. S. (1974) Critical point drying of ethanol-infiltrated, cyrofractured blological specimens for scanning electron microscopy. In: 0 . Johari (ed.), Proceedings of the Seventh Annual SEM Symposium. HTRI, Chicago.

Hyman, L. H. (1967) The Invertebrates, Vol. VI, Mollusca I. McGrawHill Book Co., New York.

Lebsack, C. S. (1976) Effect of temperature and salinity on the oxygen consumption of the chiton, Mopalia 1ignosa. Veliger 18,

Supplement, 94-97.

McGill, V. L. (1976) Responses to osmotic stress in the chiton Cyanoplax hartwegil. Veliger 18, Supplement, 109-112.

McLean, J. H. (1962) Feeding behavior of the chiton Placiphorella. Proceedings of the Malacological Society, London, 35, 23-26.

Morris, R. H., Abbott, D. P., and Haderlie, E. C. (1980) Intertidal Invertebrates of California. Stanford University Press, Stanford, California.

Nishi, R. (1976) The diet and feeding habits of Nuttallina callfornica from two contrasting habitats in central California. Veliger 18, Supplement, 30-33.

Prosser, C. L. (1973) Comparative Animal Physiology. W. B. Saunders Co., Philadelphia.

Robb, M. F. (1976) The diet of the chiton Cyanoplax hartwegii in three intertidal habitats. Veliger 18, Supplement, 34-37.

Scholander, P. F. (1950) Volumetric plastic respirometer. Review of Scientific Instruments $21,378-380$.

Simonsen, M. (1976) Response to osmotic stress in vertically separated populations of an intertidal chiton, Nuttallina californica. Veliger 18, Supplement, 113-116.

Smith, G. M. (1969) Marine Algae of the Monterey Peninsula (2nd ed.). Stanford University Press, Stanford, California.

Steneck, R. S., and Watling, L. (1982) Feeding capabilities and limitation of herbivorous molluscs: a functional approach. Marine Biology 68, 299-319. 
Stickle, W. B., and Ahokas, R. (1975) The effects of tida1 fluctuation of salinity on the hemolymph composition of several molluscs. Comparative Biochemistry and Physiology 50A, 291-296.

Stickle, W. B., and Denoux, G. J. (1976) Effects of in situ tidal salinity fluctuations on osmotic and lonic composition of body fluid in southeastern Alaska rocky intertidal fauna. Marine Biology $37,125-135$.

Winer, B. J. (1971) Statistical Principles in Experimental Design. McGraw-Hill Book Co., New York. 